\title{
ISV Technology Development Plan for Buried Waste
}

\author{
David F. Nickelson \\ Ja-Kael Luey" \\ Richard A. Callow
}

Published July 1992

\section{Idaho National Engineering Laboratory \\ EG\&G Idaho, Inc. \\ Idaho Falls, Idaho 83415}

Prepared for the

U.S. Department of Energy

Otilce of Environmental Restoration and Waste Management

Under DOE Idaho Fleld Office

Contract DE-AC07-761D01570

a. Pacific Northwest Laboratory, Richland, Washington 99352.

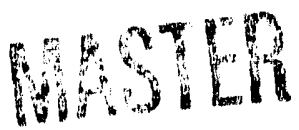


ISV Technology Development Plan for Buried Waste

EGG-WTD-10325

Prepared by:
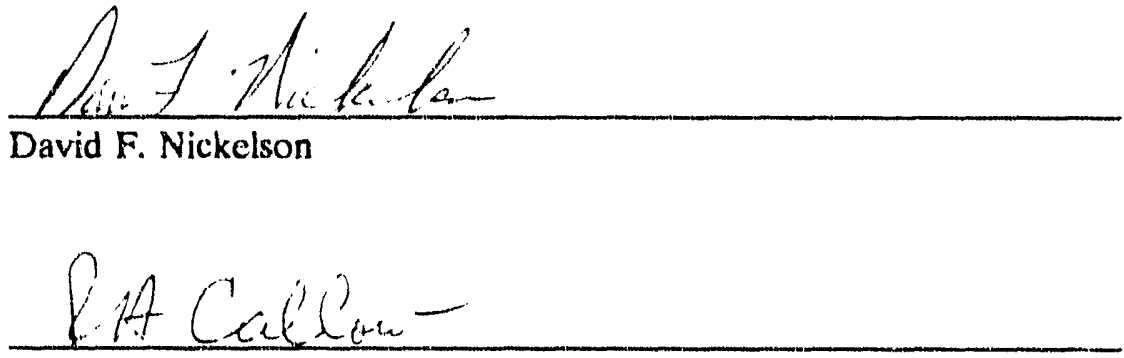

Richard A. Callow

Hon 7likele

for Ja-Kacl Ley

Reviewed by:

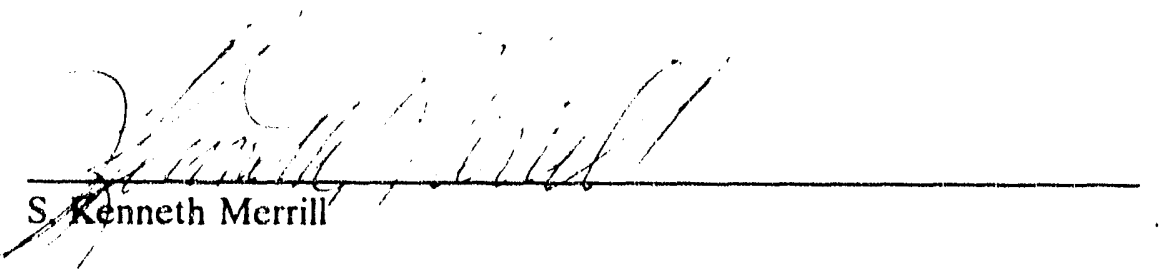

Douglass of Rut ns
$7 /: 3 / 2$

Date

$\frac{7 / 13 / 42}{\text { Date }}$

$2 / 15 / 92$

Date

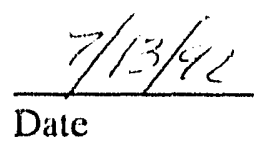

$1-13-92$

Date 


\begin{abstract}
This report identifies the main technical issues facing the in situ vitrification (ISV) application to buried waste, and presents a plan showing the top-level schedule and projected resources needed to develop and demonstrate the technology for meeting Environmental Restoration Department (ERD) needs. The plan also proposes a model strategy for the technology transier from the Depariment of Energy's Oflice of Technology Development (DOE-OTD) to the Office of Environmental Restoration (DOE-ER) as the technology proceeds from issues resolution (development) to demonstration and remedial readiness. Implementation of the plan would require $\$ 34,911 \mathrm{~K}$ in total lunding to be spread in the years FY-93 through FY-98. Of this amount, $\$ 10,183 \mathrm{~K}$ is planned to be funded by DOE-OTD through the ISV Integrated Program. The remaining arnount, $\$ 24,728 \mathrm{~K}$, is recommended to be split between the Department of Energy (DOE) Office of Technology Development $(\$ 6,670 \mathrm{~K})$ and DOE Office of Environmental Restoration $(\$ 18,058 \mathrm{~K})$.
\end{abstract}




\section{SUMMARY}

This report identilies the main technical issues facing the in situ vitrification (ISV) application to buried waste, and presents a plan showing the top-level schedule and projected resources needed to develop and demonstrate the technology for meeting Environmental Restoration Department (ERD) needs. The plan also proposes a model strategy for the technology transfer from the Department of Energy's Oflice of Technology Development (DOE-OTD) to the Office of Environmental Restoration (DOE-ER) as the technology proceeds from issues resolution (development) to demonstration and remedial readine: $\mathrm{s}$.

The plan indicates that several steps must be taken for ERD to be in a position to evaluate ISV as an alternative for application to Transuranic (TRU)-Contaminated Pits and Trenches. First, with the discontinuation of the Acid Pit field test, a separate field test is proposed in the plan to collect data for closure of issues originally planned as part of the Acid Pit test. The decision to discontinue the Acid Pit field test at the Idaho National Engineering Laboratory (INEL) means an alternative field test must be planned to collect data for closure of specific issues which were to be addressed by this test. Second, the ISV Integrated Program (ISV-IP) must allocate additional funding in the years 1993-1997 to address buried waste technical issues. Currently the ISV-IP is structured to address contaminated soil issues before proceeding to the buried waste issues. This approach will not meet the schedule needs of ERD; therefore, the proposed plan requires that additional funding be made available for adciressing buried waste issues in time to support ERD needs. Unless significant additional resources are directed to the buried waste iechnical issues, the ERD requirements for technology availability will not be met. Finally, the programmatic issue of technology transfer from development to demonstration must be resolved. An agreed-upon transfer method from OTD to ER funding must be accepted to avoid unsuccessful programmatic integration as experienced in the Acid Pit ISV project.

The total amount of funding required for ISV development and demonstration for buricd waste application is estimated as $\$ 34,911 \mathrm{~K}$. Of this amount, $\$ 10,183 \mathrm{~K}$ is currently planned to be funded by DOE-OTD through the ISV Integrated Program. Of the remaining $\$ 24,728 \mathrm{~K}$, approximately $\$ 22,871 \mathrm{~K}$ is necessary in FY 1992 through FY 1997 to allow technical input into the renedial investigation/leasibility study (RI/FS) by 1997 . An additional $\$ 1,857 \mathrm{~K}$ is required in FY 1998 to finalize data evaluation and reporting. The $\$ 24,728 \mathrm{~K}$ in funding is recommended to be split between OTD and ER, with appreximately $\$ 6,670 \mathrm{~K}$ from OTD and $\$ 18,058 \mathrm{~K}$ from ER. Because of the current uncertainty regarding ultimate disposal (i.c., at the INEL or at another DOE location), the plan provides for additional demonstration of technical feasibility of retrieval of the vitrified product for repackaging and shipment.

Previous published siudies support the potential significant cost savings for the ISV remedial option when compared with other alternatives. Additionally, the data to date support ISV as a lavorable alternative when judged by the Comprehensive Environmental Response, Compensation, and Liability Act (CERCLA) criteria. These advantages must be balanced by overall risk (technical and schedule) associated with technology development. The present plan identifies a plan for technology development and identilies major activities and decision points during development. In addition, information is included on the status of the technology, the benefits of ISV for mecting ERD needs, the technical issues remaining to be resolved, the risks associated with the ISV 
technology development, and a recommended strategy for integrating development through DOE Office of Technology Development-funded activities and ER-funded activities.

The document is organized to contain sections on (a) an overview of the buried waste remedial requirements, including technical requirements, programmatic requirements, and options, (b) ISV status, including technical stalus, technology benefits, technical issues, and current programmatic status, (c) and the ISV technology development plan. 


\section{ACKNOWLEDGMENTS}

The authors would like to acknowledge the efforts of those who contributed to this report:

- Leo Thompson (PNL) provided significant technical input into the overall logic and structure of the plan

- Jim Buelt (PNL), ISV Integrated Program Contractor Technical Coordinator, provided the input on the technology transfer plan

- Janalec Nelson provided technical editing and support for publication of the report. 


\section{CONTENTS}

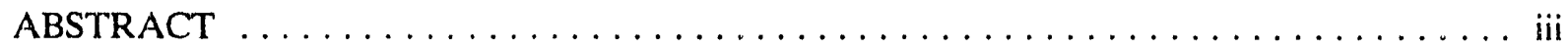

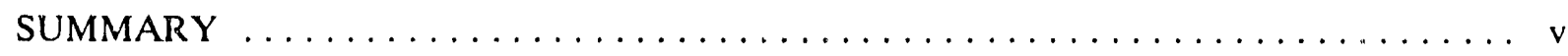

ACKNOWLEDGMENTS $\ldots \ldots \ldots \ldots \ldots \ldots \ldots \ldots \ldots \ldots \ldots \ldots \ldots \ldots$ vii

ACRONYMS $\ldots \ldots \ldots \ldots \ldots \ldots \ldots \ldots \ldots \ldots \ldots \ldots \ldots \ldots \ldots \ldots \ldots \ldots \ldots \ldots \ldots \ldots \ldots$

OVERVII W OF BURIED WASTE REMEDIAL REQUIREMENTS $\ldots \ldots \ldots \ldots \ldots \ldots$

ERD Technical Needs for Buried Wastes $\ldots \ldots \ldots \ldots \ldots \ldots \ldots \ldots \ldots \ldots$

ERD Programmatic Requirements $\ldots \ldots \ldots \ldots \ldots \ldots \ldots \ldots \ldots \ldots \ldots \ldots \ldots$

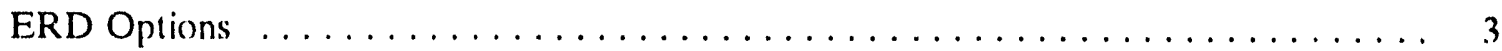

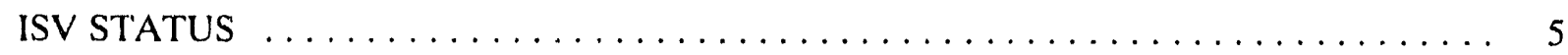

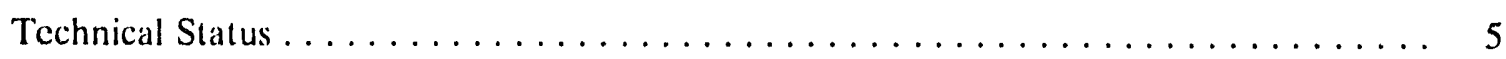

Benefits of ISV Technology $\ldots \ldots \ldots \ldots \ldots \ldots \ldots \ldots \ldots \ldots \ldots \ldots \ldots$

Buried Waste Technical lssues $\ldots \ldots \ldots \ldots \ldots \ldots \ldots \ldots \ldots \ldots \ldots \ldots$

Geosale Operational Acceptance Test $2 \ldots \ldots \ldots \ldots \ldots \ldots \ldots \ldots$

Underground Tank Vitrification Test $\ldots \ldots \ldots \ldots \ldots \ldots \ldots \ldots \ldots \ldots \ldots$

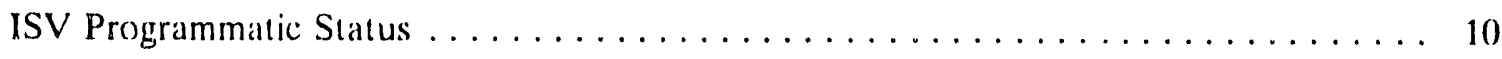

ISV TECHNOLOGY DEVELOPMENT PLAN $\ldots \ldots \ldots \ldots \ldots \ldots \ldots \ldots \ldots \ldots \ldots$

ISV Technology Development Logic Diagram $\ldots \ldots \ldots \ldots \ldots \ldots \ldots \ldots \ldots \ldots \ldots$

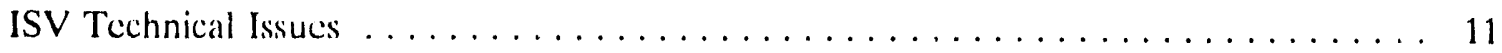

Resolution of Technical Issues $\ldots \ldots \ldots \ldots \ldots \ldots \ldots \ldots \ldots \ldots \ldots \ldots \ldots$

Technical Issue Resolution Timeline $\ldots \ldots \ldots \ldots \ldots \ldots \ldots \ldots \ldots \ldots \ldots \ldots$

Technical Issuc Resolution Budget . . . . . . . . . . . . . . . . . 20)

Applied Rescarch and Development Activity Description ............... 24

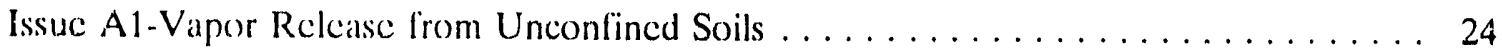




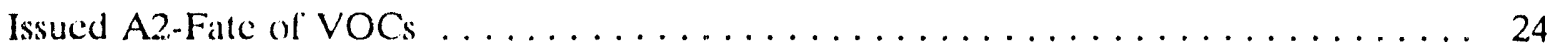

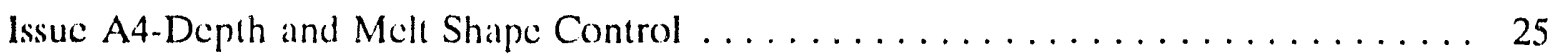

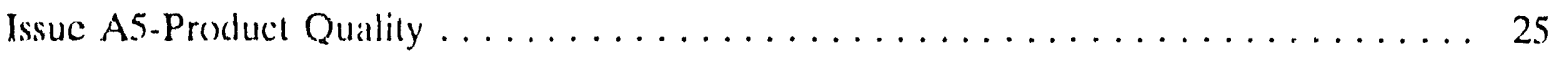

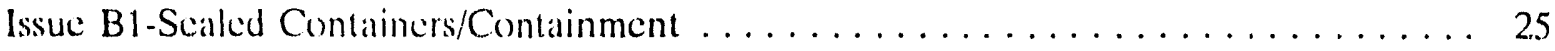

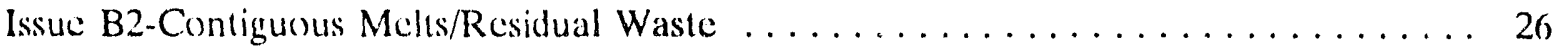

Issue B3-Contaminant Migration/Underground Fires $\ldots \ldots \ldots \ldots \ldots \ldots \ldots \ldots$

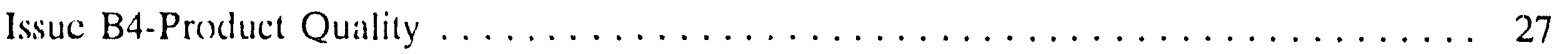

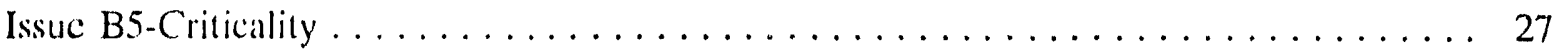

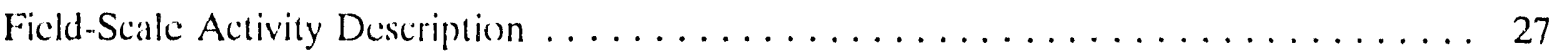

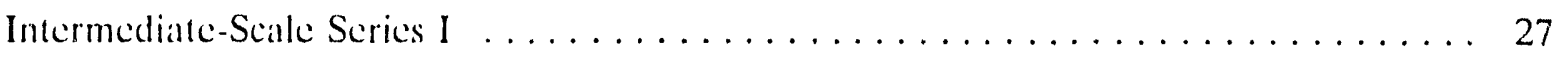

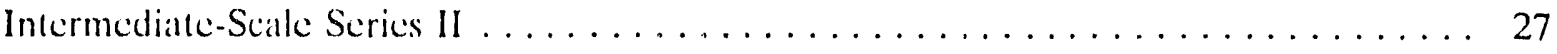

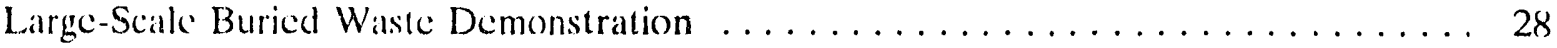

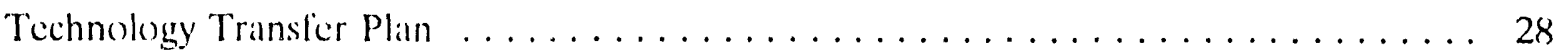

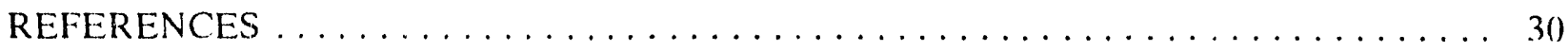

Appendix A-In Silu Vitrilication Technology Development Logic Diagram . . . . . . . . A-1

Appendix B-Budget Basis for Activities Needed for the Development of the In Situ

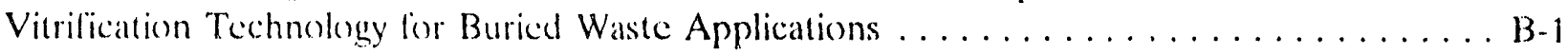

Appendix C--In Situ Vitrification Technology Transfer Plan $\ldots \ldots \ldots \ldots \ldots \ldots \ldots \ldots$ C-1

\section{FIGURES}

1. Systems cost estimate summary $\ldots \ldots \ldots \ldots \ldots \ldots \ldots \ldots \ldots \ldots \ldots \ldots \ldots \ldots$

2. Life eycle cost segment lor SDS system concepts $\ldots \ldots \ldots \ldots \ldots \ldots \ldots \ldots \ldots \ldots$

3. ISB technology development for buried waste applications-decision point summary . . 15

4. In site vitrification issues and resolution path for buricd waste application $\ldots \ldots \ldots 17$

5. ISB technology develepment timeline for buried waste application $\ldots \ldots \ldots \ldots \ldots \ldots$ 


\section{TABLES}

1. Summary makcup of wastes buried in the SDA at $\mathrm{RWMC} \ldots \ldots \ldots \ldots \ldots \ldots \ldots 2$

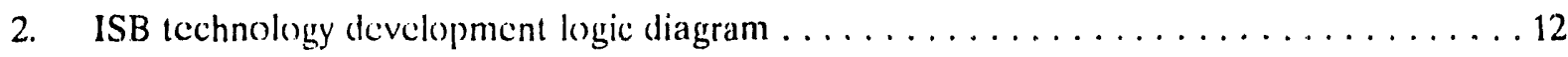

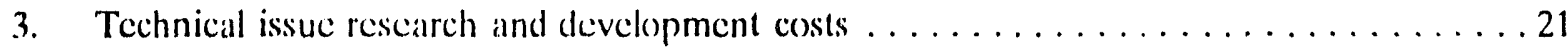

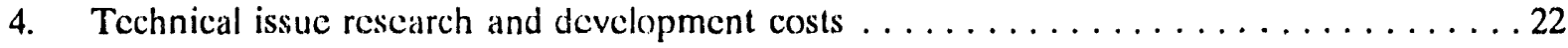

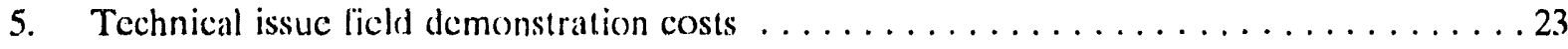




\section{ACRONYMS}

\begin{tabular}{|c|c|}
\hline DOE & Department of Energy \\
\hline ER & Environmental Restoration \\
\hline ERD & Erivironmental Restoration Department \\
\hline CERCLA & Comprehensive Environmental Response, Compensation, and Liability Act \\
\hline $\mathrm{D} \& D$ & decontamination and decommissioning \\
\hline $\mathrm{FFA} / \mathrm{CO}$ & Focleral Facilities Agreement and Consent Order \\
\hline IFT & Intermediate Field Test \\
\hline INEL & Idaho National Enginecring Laboratory \\
\hline ISV & in situ vitrification \\
\hline ISV-IP & in situ vitrification Integrated Program \\
\hline LLW & low-level waste \\
\hline ORNL & Oak Ridge National Laboratory \\
\hline OTD & Orfice of Technology Development \\
\hline OU $7 \ldots 13$ & Operable Unit 1.3 \\
\hline PNL & Pacific: Northwest Laborator: \\
\hline $\mathrm{R} \& \mathrm{D}$ & research and development \\
\hline $\mathrm{RI} / \mathrm{FS}$ & remedhil investigation/leasibility spudy \\
\hline ROI & Recerd of Decision \\
\hline RWMC & Radioactive Waste Management Complex \\
\hline SDA. & Subsurface Disposal Area \\
\hline SDS & system design situdy \\
\hline TRU & transuranic \\
\hline VOC & volatike organic compound \\
\hline WAG 7 & Waste Arca Group 7 \\
\hline WIPP & Wasste licolation Pilot Plant \\
\hline
\end{tabular}




\section{ISV Technology Development Plan for Buried Waste OVERVIEW OF BURIED WASTE REMEDIAL RE2UIREMENTS}

\section{ERD Technical Needs for Buried Wastes}

The Environmental Festoration Depar'ment (ERD) needs for buried waste remedial technologies are focussed on the Waste Area Group 7 (WAG 7), Operable Unit 13 (OU 7-13). This $O U$ is defined as the pits and trenches rontaining transuranic (TRU)-contaminated waste at the Radioactive Waste Masagement Complex (RWMC) Subsurface Disposal Area (SDA) of the Idaho National Engineering Laboratory (INEL). These wastes include TRU, low-level, and mixed waste in solid and liquid form. The waste is disposed in pits and trenches with burial depths of $4.3 \mathrm{~m} \mathrm{t}$, $7.0 \mathrm{~m}$ (14 ft to $23 \mathrm{ft}$ ). The wastes are disposed above an underlying basalt layer.

The TRU Fits and Trenches (OU-13) include the following materials:

- Soils (see Table 1):

- Approximately $113,000 \mathrm{~m}^{3}\left(4,000,000 \mathrm{ft}^{3}\right)$ of overburden soil potentially contaminat d with radionucrides, metals, inorganic compourıds, and organic compounds.

- Approximately $63,300 \mathrm{~m}^{3}\left(2,200,000 \mathrm{ft}^{3}\right)$ of underburden soil potentially contaminated with radionuclides, metals, inorganic compounds, and organic compounds.

- Approximately $\left.11,3,000 \mathrm{~m}^{3}(4,000,000) \mathrm{lt}^{3}\right)$ of interstitial soril potentially contaminated with radionuclides, metals, inorganic compounds, and organic compounds.

- Containerized Materials (sec Table 1):

- Approximately 160,53955 -gal or 120-gal steel drums assumed to be badly deteriorated.

- Approximately 6,494 cardboard boxes ranging in size from $1.22 \times 1.22 \times 2.14 \mathrm{~m} 10$ $2.67 \times 2.67 \times 5.44 \mathrm{~m}$ and weighing up to $22.70 \mathrm{~kg}(5000 \mathrm{lbs})$. The boxes are assumed to be badly deterioraled.

- Infrequent Miscellaneous Waste:

Also included in the waste materials are special types of waste including, presses, drill presses, shears, iathes, steel buoys, and steel culverts. A more detailed description. of special types of wastes is included in Table 1.

\section{ERD Programmatic Requirements}

According to the Federal Facilities Agreement and Consent Ordor (FFA/CO), a draft remedial investigation/feasibility study (RI/FS) report for the TRU-Contaminated Pits and Trenches must be 
Table 1. Summary makcup of wasles buried in the SDA at RWMC.

\section{Construction and Demolition Material}

Lumber, wallboard, steel plate and shapes, ducting, electrical wires, fuse boxes. roofing material, floor tile, insulation, lead sheet and bricks, asphalt paving matcrial, soil, sand, gravel, stecl stairways, ladders, and concrete blocks.

\section{Laboratory Equipment and Matcrials}

Hoods, laboratory benches, desks, chairs, cabinets, glassware, plastic tubing, plastic and glass bottles, solutions stabilized in concrete, plaster, or vermiculite.

\section{Prowess Equipment}

Tanks, heat exchangers, tube bundles, condensers, vacuum pumps, piping, cut up wide flange beams, valves, organic wastes, ion exchange resins, zirconium plate, zirconium turnings, sawdust, HEPA lilters, steel buoys, and steel culverts.

\section{Maintenance: Equipment}

Hand tools, metal-working machines, hoists, welders, oils and grease, metal lilings, abrasive wheels and sheet, drill presses, shear, circle shear, lathes, bridge crane with rails, casting lurnaces, and coating lumaces.

\section{Decontamination Matcrials}

Laper, rags, plastic bags and sheets, lloor sweepings, brooms, and steel wool.

\section{Miscellancous}

Sewer sludge, garbage, animal remains and excreta, jet engines, vehicles, Test Reactor Area luel end boxes, 55-gal and 120-gal stecl drums (assumed to he badly deteriorated), cardboard boxes (assumed (1) be badly delerioraled), reactor shicld, storage tanks, and keller cans.

Note: Table 1 is a listing for the entire SDA. For the purposes of this study, it is considered to be representative of the types of wastes believed to be buried in the INEL TRU-Contaminated Waste Pits and Trenches (OU 7-13). 
submitted to regulators for review by September 199'7. Therefore, technologies [such as in situ vitrification (ISV)] must be sufficiently developed such that any required treatability studies could be successfully completed and documented by September 1997 . This schedule constraint is the primary restraint that dictates requirements for technology development.

In addition to the development schedule noted above to support the RI/FS, the FFA/CO requires that the Remedial Design/Remedial Action process be strcamilined such that the Comprehensive Environmental Response, Compensation, and Liability Act (CERCLA) requirement is met to begin substantial continuous physical on-site remedial aclion within 15 months of issuing a Record of Decision (ROD). The anticipated ROD date is 1999, which means a technology must be developed such that substantial actual remediation could start in the year 2000 .

\section{ERD Options}

The remediation of buried transuranic waste at the INEL has been identified as an area where proven technical solutions do not currently exist. ${ }^{1}$ The primary option being investigated by ERD at the present time is retrieval and subsequent treatment of the waste. The actual technologies for doing this are based on the on-going work on Pit 9 remediation at the INEL. Pit 9 is a TRU-contaminated buried waste pit which is slated for carly remedial action. The current Pit 9 project is directed at soliciting, evaluating, and demonstrating technologies available in the private sector that can be used for remediating Pit 9 materials. At present, the preferred alternative is chemical/physical extraction of the TRU contamination; however, the details of the process(es) have not been evaluated. Until the exact processes have been defined and successfully demonstrated, ERD is accepting the risks that the processes will not be elfective, or may require significant costly and time consuming technical developınent. It is likely that the Pit 9 work will provide some essential information on the retrieval/treat option for OU-13 waste. However, the OU-13 waste is likely to have more varied and complex remedial requirements that the Pit 9 waste; if so, additional or alternative strategies may be required.

During evaluation of treatment alternatives, ERD will be required to balance factors such as effectiveness, implementability, and costs. Comparison of costs, in a 1991 preliminary system design study (SDS), ${ }^{2}$ showed that ISV treatment was approximately 6 to 10 times less costly that o"her treatment options which involved retricval and subsequent treatment and/or packaging, and disposal. A combination of ISV and post-processing retrieval was also less costly than other options studied. These data support the SDS recommendation that the ISV concept be explored further as a potential option.

Selection of remedial alternatives by ERD will also require balancing of both technical and political considerations consistent with the CERCLA process under the FFA/CO. Given the previous commitments made by federal agencies to the State of Idaho, the removal of both the stored and buried waste from Idaho may ultimately be necessary; this waste includes the buried waste in OU-13. A removal requirement may represent a source of controversy since it is possible that CERCLA considerations may point to a preferred option not involving interstate transportation. Nevertheless, the current ERD position dictates that ultimate removal be considered. For an ISV treatment, this means that the vitrified block would be removed from the ground and transported to the final 
disposal site. Appropriate studies must, therefore, be performed to establish that current technology with, at most, minor development can allow for safe and effective removal of the vitrified product.

Despite political considerations dictating that ERD be prepared to present remedial strategies that involve ultimate disposal at a location outside of Idaho, it is prudent for ERD to seriously consider options for ultimate disposal at the INEL. Although the political climate within Idaho may favor off-site disposal, there is no off-site location identified for this disposal and it is unlikely that another state will voluntarily accept this waste. Recent conflicts between the Department of Energy (DOE) and the state of New Mexico over the Waste Isolation Pilot Plant (WIPP) repository, and between DOE and the state of Nevada over the Yucca Mountain repository do not offer much encouragement that non-INEL siting and disposal of the INEL buried waste will occur easily. ERD must make reasonable progress on alternatives to the current planned physical/chemical treatments planned for Pit 9 and alternatives involving ultimate on-site treatment and disposal if they hope to have fall-back options if unacceptable problems and delays occur during Pit 9 remediation, or if no off-site disposal location can be identified.

The SDS results indicate that the ISV option offers a potential significant cost savings for the remediation of TRU buried waste. This savings is associated with some risk. The ISV technology must be developed in order to support the ERD needs. As for any technology, including retricval/treat options, the successful development is not guaranteed, at least for the assumed costs. The uncertainties of technology development are also significant, given the current FFA/CO schedule. Under the curreat schedule, any unanticipated delays or new issues will likely alfect the ability to support the FFA/CO schedule for the ROD. However, the uncertaintics associated with ISV development must be considered in view of other remedial options, their relative remedial costs, and their associated technical uncertainties. 


\section{ISV STATUS}

\section{Technical Status}

The ISV technology has been under development since 1980. Initial development efforts at Pacific Northwest Laboratory (PNL) were directed at contaminated soil applications. The technology is now considered ready for limited deployment on contaminated soil applications, and it has been transferred to a licensee (Geosafe) for commercial applications. Evaluation of ISV for application at specific sites has resulted in 10 sites at which the Record of Decision (ROD) indicates ISV as the preferred or acceptable alternative candidate. Of these sites, six are probable candidates-two of which are Department of Defense sites. Total size of site remediation required ranges from a few hundred tons to approximately 40,000 tons. (Current capacity is about 15,000 tons/machine/year.) Current Geosafe plans estimate initial remediation to begin in 1993. This schedule is delayed from the original plans due to events occurring during a 1991 operational acceptance test, as discussed in more detail later.

Encouraged by the early results for contaminated soil application, both the INEL and Oak Ridge National Laboratory (ORNL) established cooperative efforts with PNL to investigate applications to specific site needs. For buried waste development and remediation, INEL and PNL established a joint program in 1988. Initial laboratory tests ${ }^{3}$ were encouraging and results warranted proceeding to feasibility testing at field scale. The 1990 Intermediate Field Tests (IFT) at the INEL were successfully completed, indicating the feasibility of ISV for buried waste application. ${ }^{4}$ Of particular note was the successful incorporation of simulated buried waste (including high combustible and metal content) into a durable glass and crystalline product with excellent physical characteristics, as evidenced by leach data. Significant volume reductions (up to 75\%) were observed. Transient pressure and temperature spikes were observed in the off-gas hood indicating a need to understand this issue and develop more robust equipment and operating procedures for processing containerized waste. These issues, as well as others defined prior to and during the IFTs, were incorporated into the overall issue identification and prioritization effort as described below.

In addition to the field tests, substantial effort was directed at development of an analytical modeling capability to support the resolution of technical issues, as well as support safety and environmental studies. These efforts have resulted to date in the development and application of several codes to model the primary physical phenomena affecting the process. ${ }^{5,6,7}$ Detailed validation of the initial code results and integration of codes to study combined physical effects remains to be done.

\section{Benefits of ISV Technology}

Research and development data indicate several potential bencfits of ISV for remediation of buried transuranic waste. Major benefits of the technology include the following:

- Incorporation of inorganics into a durable product. Test results to date ${ }^{4,8}$ indicate that the durabilities of the ISV products greatly exceed the durability of a typical high-level waste form. Both radionuclides and hazardous metals are dissolved into the molten mass and incorporated into the waste form. (Volatile materials are captured in the off-gas 
processing system.) Data indicate that the durability of the ISV product is comparable to obsidian or granite, natural analogs which have been observed to be durable for geologic time periods.

Although some work remains for assessing durabilities of specific product phases resulting from processing of buried waste with high metal content, the current data indicate that the ISV product has low enough leachability characteristics to support leaving the processed product in place. However, the option to remove the vitrified product for final disposal elsewhere is viable. If removal is required, the removal of a vitrified product will likely be significantly safer than removal of unprocessed waste.

- Destruction of organics by high temperature. The high temperatures obtained during processing $\left(1500-2000^{\circ} \mathrm{C}\right)$ are sufficient to destroy volatile organic materials. This eliminates concerns associated with these particular components of the waste and can result in a change in classification of the waste from mixed to low-level waste (LLW) or TRU. As indicat d below, additional research is necessary to fully evaluate the transport of volatile organics in the vicinity of a melt.

- Volume reduction of waste. Vitrification of soils results in a volume reduction of approximately $30-40 \%$ due to the densification of the vitrificd product relative to normal soil. For cases of huried waste, with more void space in the waste region, the expected volume reduction is greater. Test data (see Reierence 4) indicate volume reductions up to approximately $75 \%$.

- Ability to process heterogeneous wastes. Test results to date are encouraging in showing the ability of ISV to handle a mixture of waste types. Although the exact limits of processing ability are not yet defined, the feasibility field testing for buried waste processing shows successful ability to process high combustible $(2.5 \mathrm{w}(\%)$ and high metal (11 wt\%) content waste in both randomly disposed and stacked configurations (see Reference 4). The ability to handle heterogeneous waste reduces the complications and costs associated with waste stream separation into fractions for specific treatments. Such separations may be necessary for ex-situ treatment alternatives

- Lile cycle cost savings. In 1991 a preliminary system design study was performed $(0$ evaluate various options for the treatment of buried waste at the INEL (sec Reference 2). This evaluation included implementability, effectiveness, and cost. Figure 1 (Figure I-1 of SDS, Volume 1) shows the relative estimated costs (rough order-of-magnitude) for various options. It should be noted that the preliminary SDS results (Figure 1) did not include the transportation, disposal, and facility decontamination and decommissioning (D\&D) costs in the total life cycle. These have now been evaluated in subsequent studies" and are shown on Figure 2. The cost data shown in the figures indicate that significant life cycle cost savings may result from remediation using either ISV or ISV/retrieve options. 


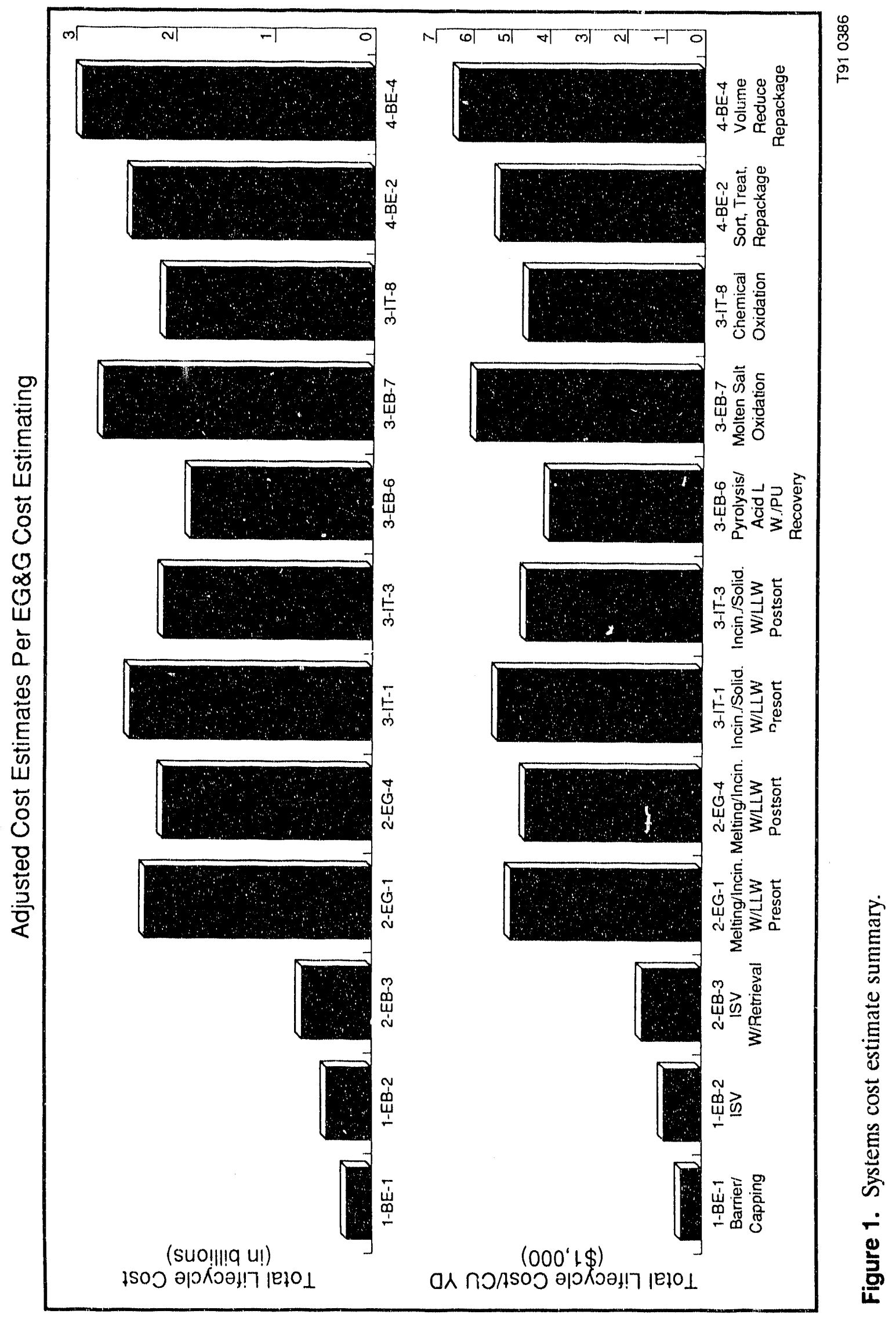




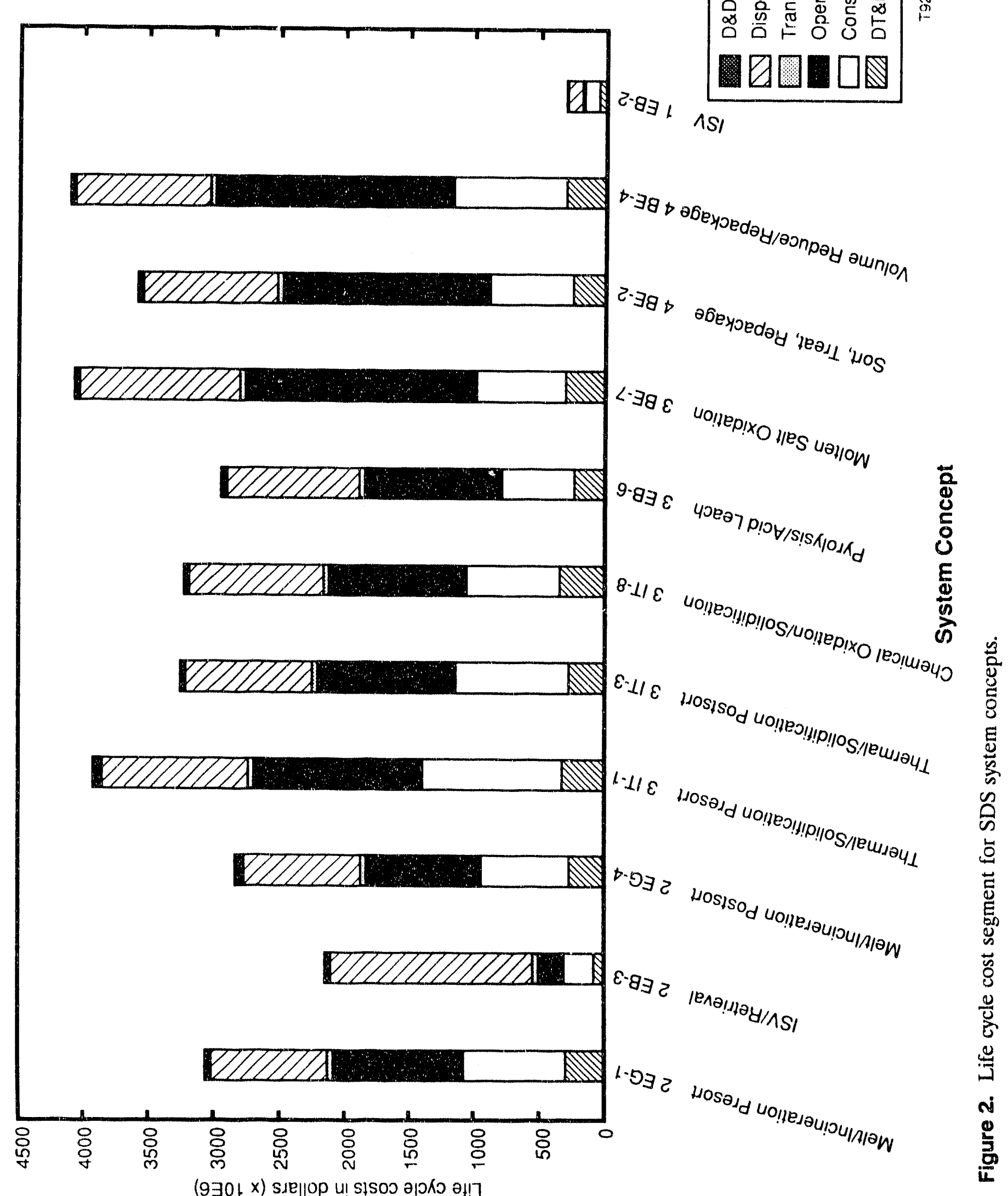




\section{Buried Waste Technical Issues}

The benefits of ISV must be balanced by the costs and risks involved with technology development. Although feasibility has been clearly shown, ISV is not currently developed and demonstrated for application to buried waste.

As part of technology evaluation and development, previous work at the INEL and PNL has also focussed on identifying and prioritizing the buried waste technical issues, and preparing closure plans for each technical issue. Thuse efforts have been published as Reference 10 and provide the technical baseline for current planning. Advances in equipment design and process knowledge data indicate that many technical issues investigated to data have been or can be satisfactorily addressed.

In parallel with the evaluation of ISV for application to buried waste, additional testing for other applications were performed. Several of these tests have indicated issues that need to be addressed for all applications, including contaminated soils. Two tests during 1991 of special note are the Geosafe Operational Acceptance Test 2 and the Underground Tank Vitrification test conducted on a simulated underground tank at Hanford.

\section{Geosafe Operational Acceptance Test 2}

In this full-scale test approximately 20 tons of molten glass was ejected from the melt in a single event. Post-test observations indicated that the molten glass appeared to be ejected as part of a single large bubble (approximately $3 \mathrm{~m}$ in diameter). An accident investigation was conducted which was not entirely conclusive; however, major contributing factors appeared to be the specific test setup which had 55-gallon drums containing water-saturated sand buried in an underground array. Concrete walls on three sides of the melt were also potential contributors to a scenario in which confined water (liquid/vapor) underneath the melt eventually led to an eruptive discharge through the melt. An additional factor was the unusual melt shape which developed; this shape was probably duc in part to the use of a fixed electrode configuration for this test.

\section{Underground Tank Vitrification Test}

This full-scale test was conducted on a full-scale mock-up of an underground storage tank. The test was terminated when molten glass erupted from the melt, damaging the off-gas hood. Investigation into the event is still in process; however, the generation of several large diameter bubbles is suspected to be the cause of the glass eruption. An obvious potential contributing factor was the tank walls, which confined the vapor underneath the melt.

The above test results indicate that the behavior of water vapor underneath and adjacent to an ISV melt must be better understood. The seriousness of this particular issue derives from the safety risks involved with expulsion of molten material from the melt.

Issues of concern to the ISV community in general, as opposed 10 issues for specific applications, have been identified through the above tests and others, including testing done at Oak 
Ridge National Laboratory (ORNL). Based on testing to date, four major contaminated soil issues (applicable to other ISV uses as well) have been noted:

- Vapor release (melt ejection)

- Contaminant transport of volatile organic compounds (VOCs)

- Melt depth and shape control and verification

- Operational issues relative to sites with high concentrations of Cs.

\section{ISV Programmatic Status}

In response to the results of testing and the identification of key technical issues applicable to multiple ISV applications, the ISV Integrated Program (ISV-IP) was established in 1991. The purpose of the ISV-IP is to coordinate and focus efforts in the ISV community and provide technical direction. The ISV-IP identified the need to address the contaminated soil issues noted above and proposed a program to meet the needs. (This is discussed in more detail below.)

The INEL ISV Acid Pit project was initiated in 1991 to assess the applicability of ISV for remediation of the Acid Pit. The Acid Pit ISV project was initiated prior to characterization from the Acid Pit so assumptions regarding contamination amounts were made. The program was also planned under the assumption of joint funding from DOE Environmental Restoration (DOE-ER) and DOE Oflice of Technology Development (DOE-OTD) for accomplishing the overall task. The OTD lunding was to support resolution of issues, primarily the melt ejection iseue which must be satisfactorily addressed prior to lield testing.

Site characterization results indicating low levels of risk resulting in no need for an interim action and lack of progress on technical issue resolution (no funding ivas made available) resulted in the decision to discontinue the Acid Pit ISV field testing. However, the main technical issues to be investigated as part of the Acid Pit ISV project are now being initiated under OTD lunding. Detailed plans for issue resolution are being finalized.

Given the present state of alfairs, several things are needed if ERD is to have any hope of fairly evaluating ISV as a legitimate alternative lor application to TRU-Contaminated Pits and Trenches. First, the contaminated soils issues must be resolved since these issues are applicable to the buried waste application as well. The decision to discontinue the Acid Pit field test means that an alternative field test must be planned to collect data for closure of specific issues which are to be addressed by this test. Second, the ISV-IP needs to initiate a program to supplement the current contaminated soil program. Unless significant additional resources are directed to the buried waste technical issues, the ERD requirements for technology availability will not be met. Finally, the programmatic issue of technology transler for development to demonstration must be resolved. An agreed upon method for integration of OTD and ER responsibilities and funding must be aceepted (1) avoid unsucecssful programmatic integration as experienced in the Acid Pit ISV project. 


\section{ISV TECHNOLOGY DEVELOPMENT PLAN}

The purpose of this in situ vitrification (ISV) technology development plan is to outline the necessary activities, and associated schedule and budget, and to develop the ISV technology for application to buried waste. These development activities are driven by the need to resolve technical issues associated with the appliciation of ISV 10 buried waste. In addition, the schedule for these development activities is driven by the rieed to obtain sufficient data to allow an evaluation of the ISV technology for the 1998 Record of Decision (ROD) for the INEL Operable Unit 13 (OU-13).

\section{ISV Technology Development Logic Diagram}

Table 2 illustrates the first four tiers of the ISV Technology Development Logic Diagram. The Logic Diagram illustrates the "logic" behind the need to perform applied research and development (R\&D) activities to resolve technical issues (see Appendix A for detail of R\&D activities needed to close technical issues). The schedule for resolution of these technical issues is driven by the ROD for a particular site. Once technical issues for a given application are resolved, the ISV technology will be a viable remedial action solution for that given application. For example, if the only issue for a contaminated soil site is depth (current limitation is 5 meters), then resolution of the depth technical issue would make ISV a viable remedial action alternative for that particular site.

Two problems are illustrated in Table 2, remediation of contaminated soils and i mediation of buried waste sites. The issues in bold type are ones whose resolution are necessary for the development of the ISV technology for application to buried waste. Some issues for contaminated soils are highlighted because the fundamental understanding of these issues regarding vitrification of contaminated soils provides the basis upon which a fundamental understanding of issues regarding vitrification of buried waste will be built upon. The technical relationships between issues associated with vitrification of contaminated soil and buried waste is discussed in the following sections.

\section{ISV Technical Issues}

Between 1988 and 1991, the Pacific Northwest Laboratory (PNL) and Idaho National Engineering Laboratory (INEL) pursued a collaborative effort to determine the feasibility of the ISV technology for application to buried waste. Included in this effort was an intermediate-scale field test in 1990 (see Reference 4) that demonstrated the feasibility of the ISV technology, as well as technical issues that must be resolved. A number of technical issues were identilied by an ISV Steering Committee formed at the INEL (see Reference 10) all of which can be categorized into the first five buried waste issues identified in Table 2 . These issues are:

- B1 Sealed Containers/Containment-The prevention and/or control of transient gas releases which result from ISV processing of sealed containers, specifically drums.

- B2 Contiguous Melts/Residual Waste-The ability to control melt shape and depth, in a buried waste environment, to ensure the formation of contiguous melts and the minimization of residual or unprocessed waste.

- B3 Contaminant Migration/Underground Fires-The minimization of contaminant migration into the surrounding soil and the prevention of underground lires spreading to an area outside that of the ofl-gas hood. 


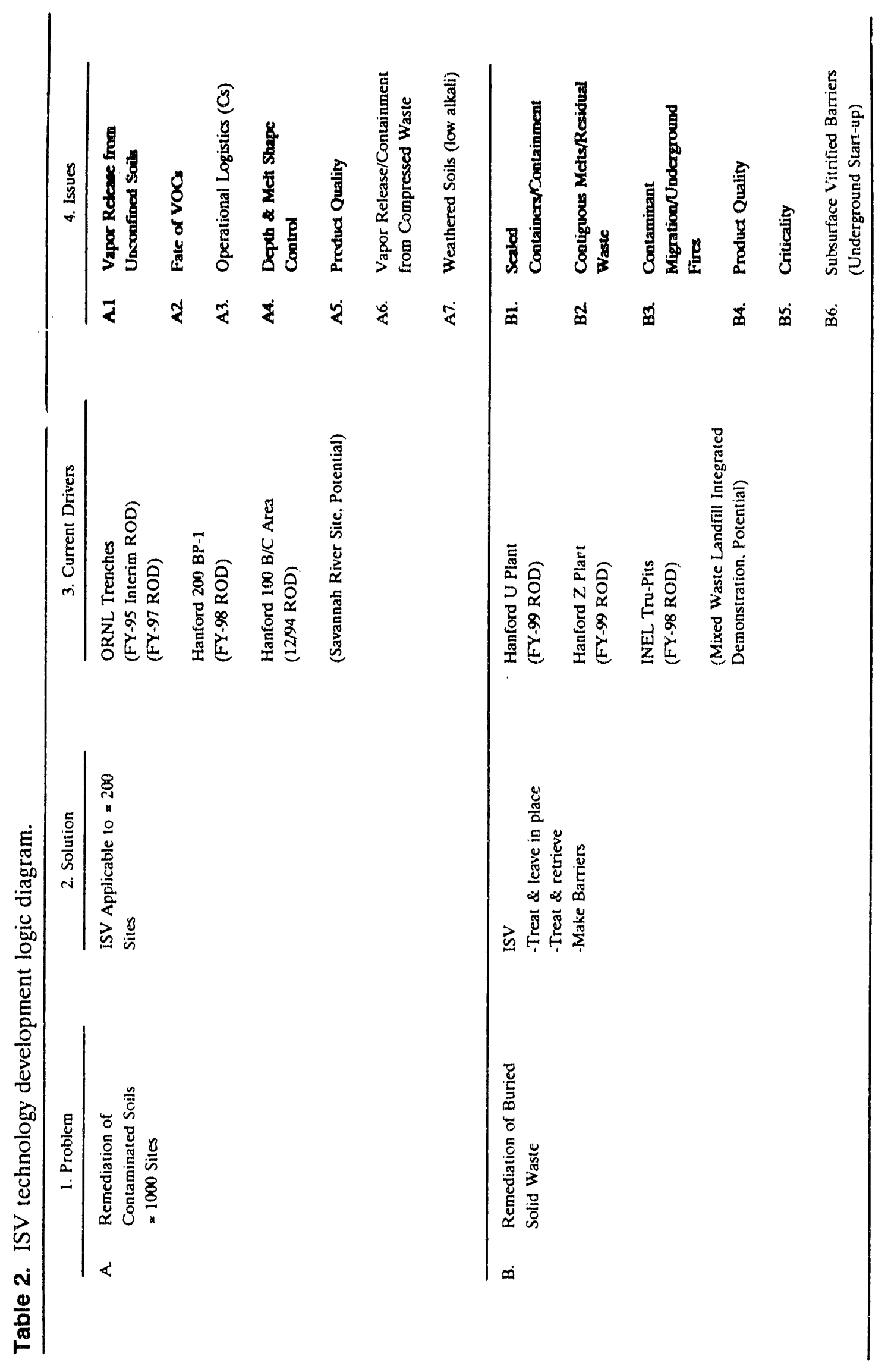


- B4 Product Quality-Demonstrate the long-lerm stability ard acceptability of the ISV product, as well as potential metal phases formed due to the high metal content expected in a buried waste site.

- B5 Criticality-Demonstrate the ability of the ISV process to avoid the eoneentration of fissile materials and subsequent potential lor a criticality.

The resolution of these technical issues for ISV application to buried waste requires an understanding of the fundamental mechanisms underlying each technical issuc. For example, the issue of sealed containers/containment stems from observations during the 1990 field test in which the ISV off-gas containment hood experienced transient pressure and temperature spikes (sec Reference 4). The cause of these transient events is believed to be the rapid release of gases from sealed containers that were placed in the test site to simulate buried waste. Closure of this issue requires an understanding of how gases are generated in a sealed container, how the gases escape a container, how they move through and/or around an ISV melt, and how the evolved gases ultimately affect the off-gas containment hood (e.g., pressure, temperature).

Except for the presence of the sealed containers, the fundamental understanding required to close the issue of sealed containers/containment is identical to the understanding necessary to close the contaminated soil issue of vapor release from unconfined soils. Closure of this contaminated soil issue requires an understanding of how gases are generated below an ISV melt, how the gases move through and/or around an ISV melt, and how the evolved gases ultimately affect the off-gas containment hood (e.g., pressure, temperature, and off-gas flowrates).

This overlap of underlying mechanisms for the issue of vapor release from unconfined soils and the issue of sealed containers/containment underscores the relationship between certain issues for contaminated soils and issues for buried waste. Other such technical relationships include:

- B2 Contiguous Melts/Residual Waste and A4, Depth and Melt Shape Control

- B3 Contaminant Migration/Underground Fires and A2, Fate of VOCs

- B4 Product Quality and A5, Product Quality.

For each of these technical issues, the fundamental understanding developed for contaminated soil applications provides the necessary groundwork fir a fundamental understanding for issues regarding the vitrification of buried waste.

\section{Resolution of Technical Issues}

The resolution of technical issues for the ISV technology often requires a combination of applied research and development (R\&D) activities with lield data for verification. The applice $R \& D$ activities include technical assessments, engineering calculations, computer modelling, crucible and bench-scale single effects testing, and engineering-scale ISV testing. Field data is needed to provide for verification of predictions and to assist in the resolution of any scaling issues that may be present. The decision to proceed with a field-scale test to obtain the necessary verification data is dependent upon the level of understanding obtained via the applied $R \& D$ activities. 
Figure 3 illustrates the top-level decision points for the development of the ISV technology for application to buried waste. Consistent with the discussion of the ISV technical issues, the decision path for the ISV buried waste development is integrally tied to the development of ISV for contaminated soils. The ultimate goal of the ISV technology development for buried waste is to be in a position to provide data to the Remedial Investigation/Feasibility Study (RI/FS) report that will support the ROD for the INEL Operable Unit 13 (OU-13). To reach this goal, the ISV technology must demonstrate its utility for buried waste through applied $R \& D$ activities and a series of field-scale verification tests. As shown in Figure 3, the path between applied R\&D and the linal R\&D contains many key decision points.

The decision points in Figure 3 provide checks for the ISV technology development and allow an evaluation of the merits for further development of the technology for buried waste. A key decision point is whether data obtained via a staged soil site supports proceeding with field tests designed for buried waste. This fundamental data will be used to evaluate whether the understanding of the ISV process for contaminated soils, which is much simpler than buried waste, is sufficient to warrant proceeding with activities to understand the more complex behavior inherent with processing buried waste. For example, data that resolve the issue of vapor release from unconfined soils are necessary so that studies involving buried waste can separate the effects attributed to soil properties from those attributed to the buried waste.

Once the decision to proceed with further development of ISV for buried waste is made, buriced waste $R \& D$ efforts for issues resolution will be refined so that the necessary data to be collected from the intermediate-scale series II field testing is identified. Intermediate-scale test series II is envisioned to include one test to investigate single parameter effects (c.g., sealed containers, container content composition) and one test that simulates a scaled-down buried waste site. The results from this test series will be used to evaluate the merits of pursuing the ISV technology development for buried waste to a full-scale demonstration. Such a full-scale demonstration would demonstrate the ISV technology at a production scale and provide the necessary data to close the ISV buried waste lechnical issues as well as provide the data necessary for the Rl/FS report lor the OU-13 ROD.

Figure 4 illustrates the issue resolution path for the development of ISV for application to huried waste. As with the decision summary presented in Figure 3, the issue resolution path for buried waste shows the relationship hetween activities needed to resolve issues for contaminated soils and those activities needed to resolve issues associated with buried waste. Applied R\&D activities feed information into the planning of the field-scale tests so that the required information is collected from these field-scale tests. The information from these field-scale tests is then entered back into the applied R\&D tools to verify predicled resuits. This information bycle, and the associated communication required, is an integral part of the issue resolution strategy.

\section{Techrical Issue Resolution Timeline:}

Figure 5 illustrates the estimated time duration for the completion of activities needed to develop the ISV tachnology lor buried waste. Included in this tirneline are the activities for the resolution of contaminated soil issues which provide the foundation for activities to resolve burice waste issues. The limeframe for resslution of technical issues is shown to illustrate the interactive nature of the applied R\&D activities and the field-scale testing activities. As discussed previously lor the decision print summary and the issue resolution path, the applied R\&D activities identily the 


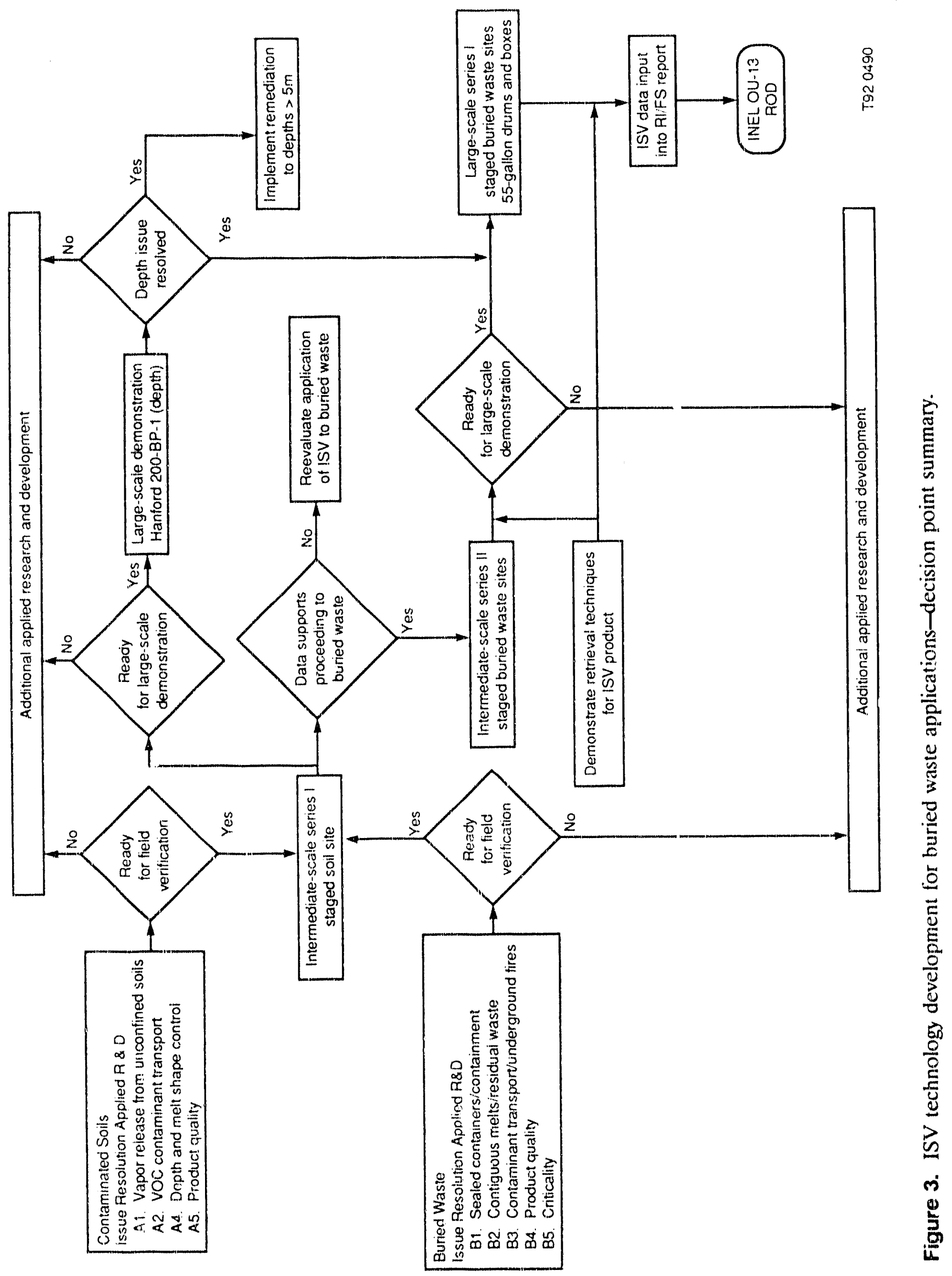




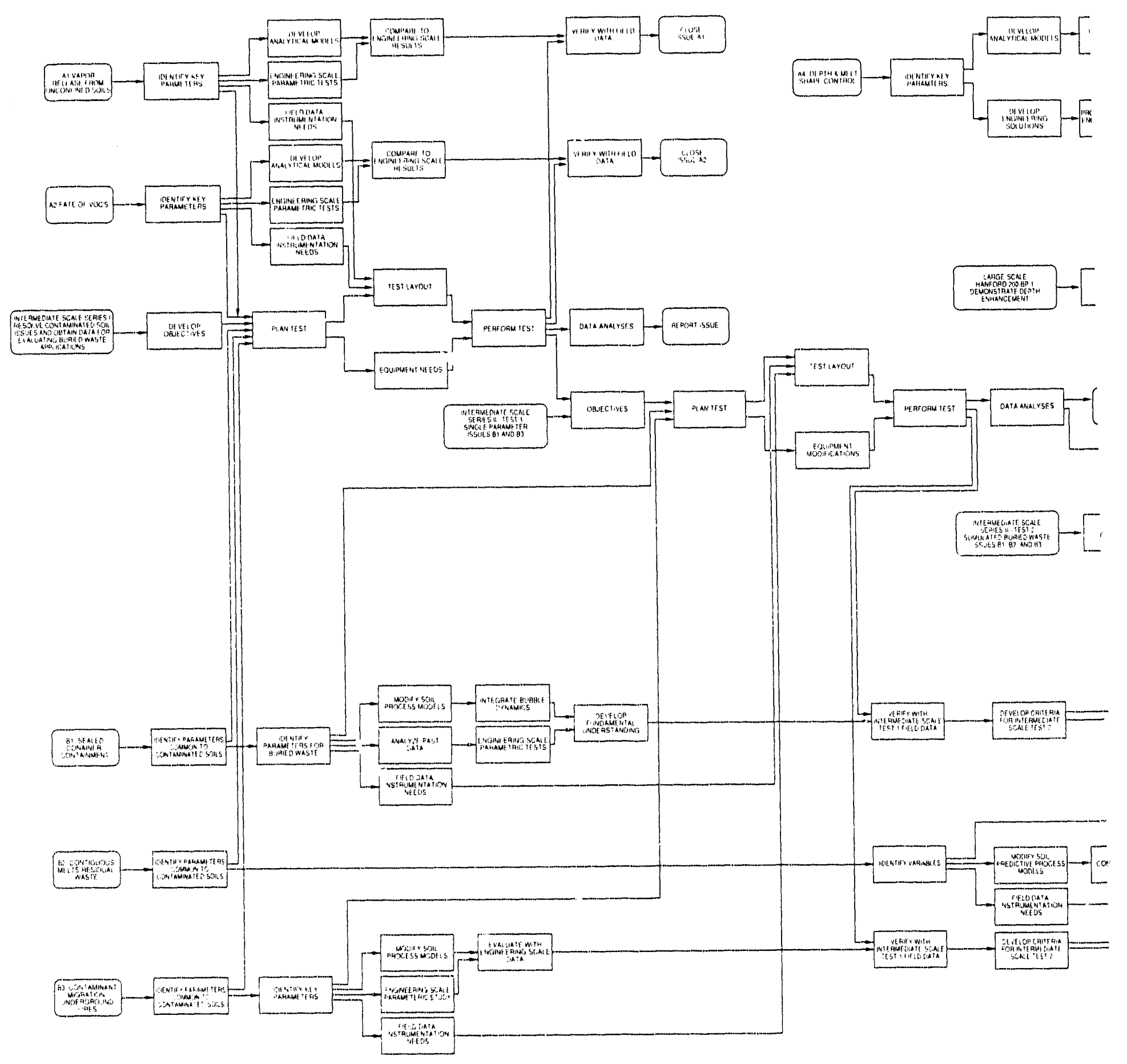

Figure 4. In situ vitrification issues and resolution path for buried waste application. 


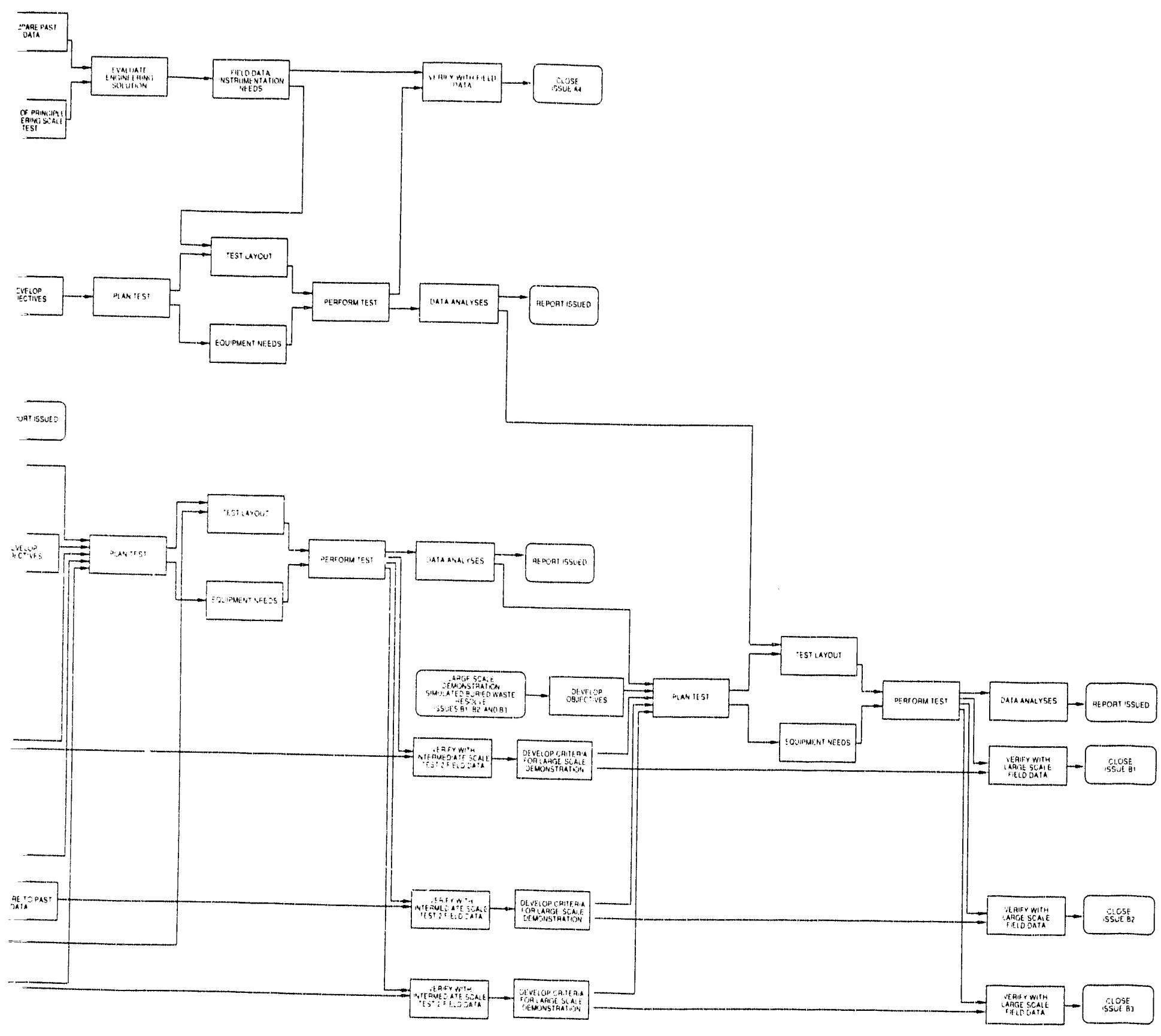




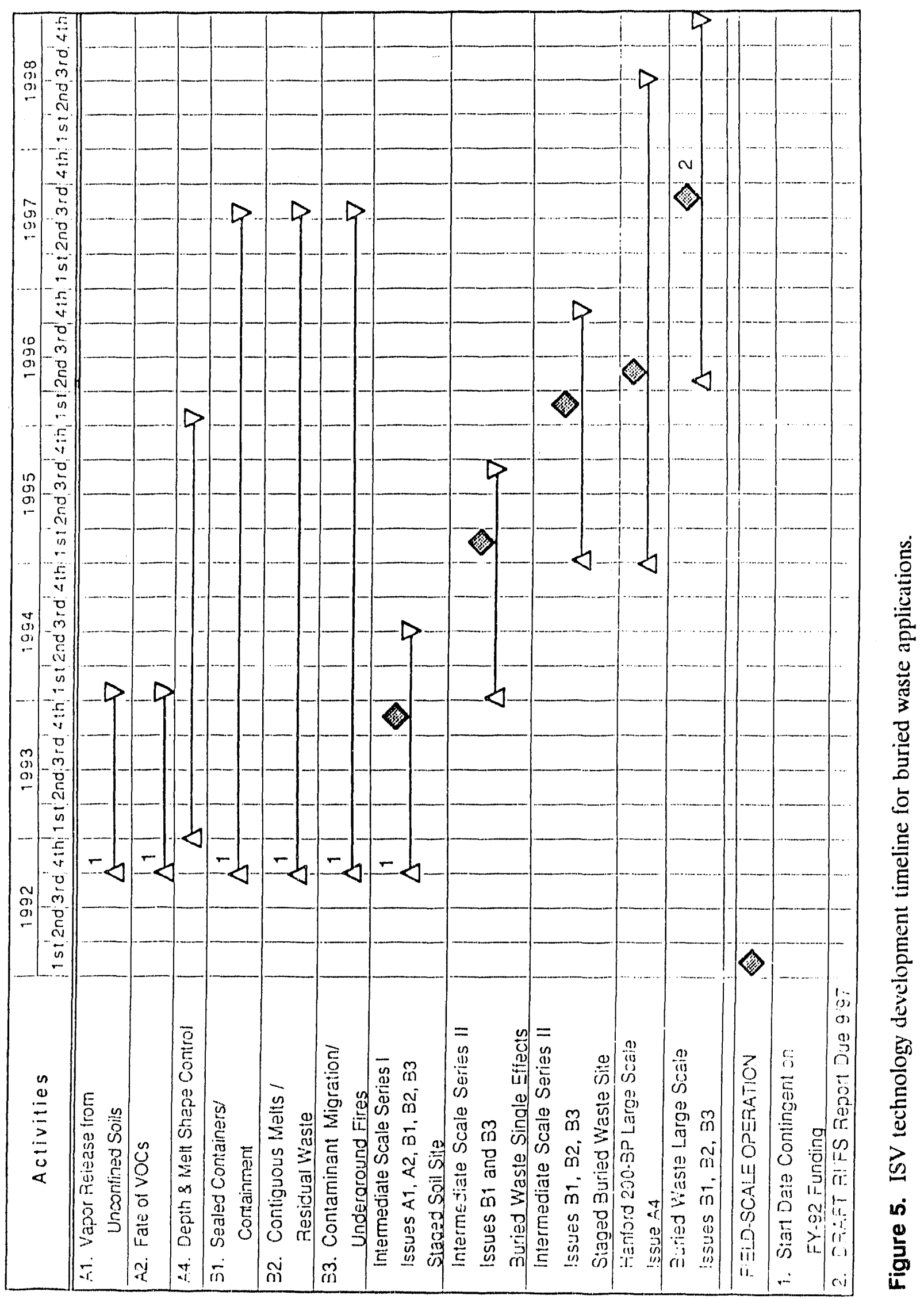


necessary field-scale data, the field-scale test is designed and performed, and the resulting data entered back into the applied R\&D activity for verification of developed tools. Figure 5 also identifies the estimated time for performance of the various field-scale tests.

The interdependency between applied R\&D activities and field-scale activities have been shown previously in Figures 3 and 4 . This relationship underseores the need for a coordinated efleort between the two parallel paths. Delays in either the R\&D path or the lickd-scale path will have significant impact on the other path, as well as future activities. For example, a delay in completing intermediate-scale series I will directly impact the timeline for resolution of technical issues for both contaminated soils and buried waste and may ultimately impact the ability of the ISV technology to support the RI/FS report. Recovery from such delays are possible, especially if they occur early in the timeline, but will require an adjustment of schedules and budgets. As a result of this potential, a minimum yearly review of technical progress and schedule status is planned for the development of ISV for application to buried waste.

\section{Technical Issue Resolution Budget}

Sinc 1980, ISV has grown from a concept to an emerging technology through modelling and engincering calculations supported by the data from a series of bench-, engineering-, intermediate-, and large-scale tests. Applied R\&D activities consist of these modelling and engineering calculations as well as proof-of-principle work at the bench- and engineering-scale levels. In addition, more than 40 previous ISV intermediate- and large-scale tests have been performed to demonstrate the ISV technology at the field level. This experience in conducting applied R\&D activities and field-scale demonstrations provides the basis for the estimated budget for ISV lechnology development for buried waste applications.

The estimated costs to develop ISV for application to buried wastes are shown in Tables 3, 4, and 5 and presented in more detail in Appendix B. As discussed previously, it is necessary to resolve issues for contaminated soil applications in order to provide a technical basis for the resolution of buried waste application issues. The estimated costs to resolve contaminated soil issues are shown in Table 3. Funding sources have already been identified for much of the contaminated soil work shown in Table 3 (authorization of funds for use is dependent upon approval). The funding source for much of the applied R\&D work is from the Oflice of Technology Development via the ISV Integrated Program, and the funding source for the large-scale demonstration for resolution of the depth issue is through the Westinghouse Hanford Environmental Restoration Program.

The estimated R\&D costs for resolution of issues specific to the buried waste application are shown in Table 4. The bulk of these costs occur in FY-93 through FY-96. However, some costs will occur in FY-98 as part of validation of issue resolution using data from the large-scale field test and associated reporting and documentation. The costs shown in Table 3 are recommended to be funded through DOE-OTD since they result from applied research activities.

The estimated lield demonstration costs associate with issue resolution and technology licld demonstration are shown in Table 5. These costs oicur in FY-93 through FY-98 and are recommended $t o$ be funded through DOE-ER since they are associated with lield demonstration of the technology for specific site applications. The costs for FY-98 are for final documentation and reporting results of the large-scale field demonstration. It is anticipated that the results of the largescale tests will be evaluated to support the FY-97 data needs for the RI/FS; however, final test reporting will not occur until FY-98. 


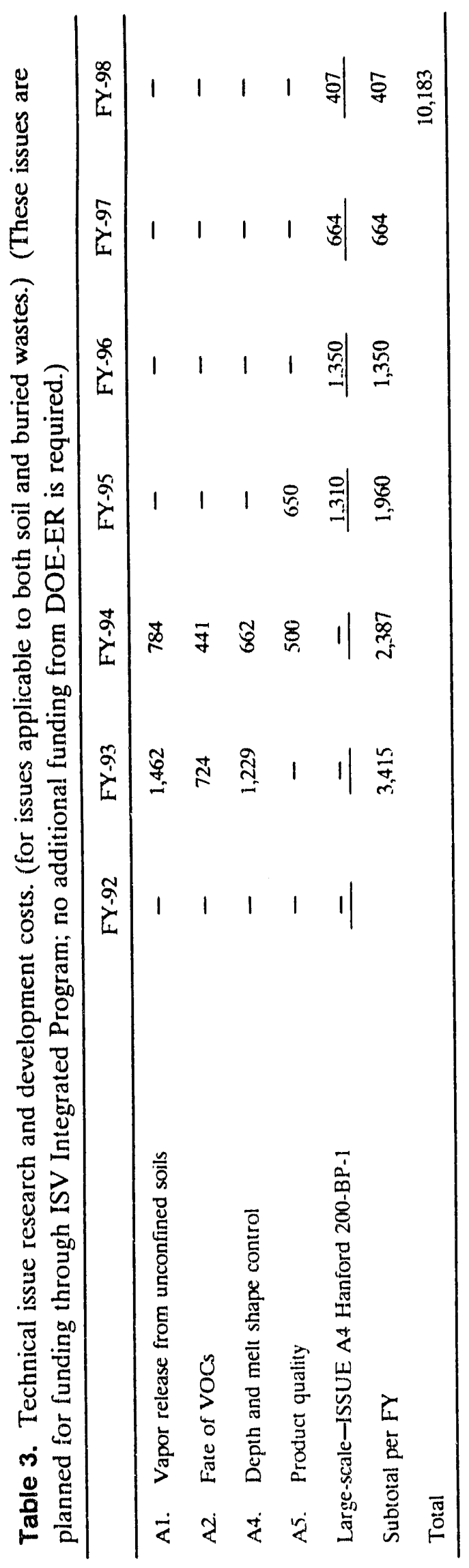




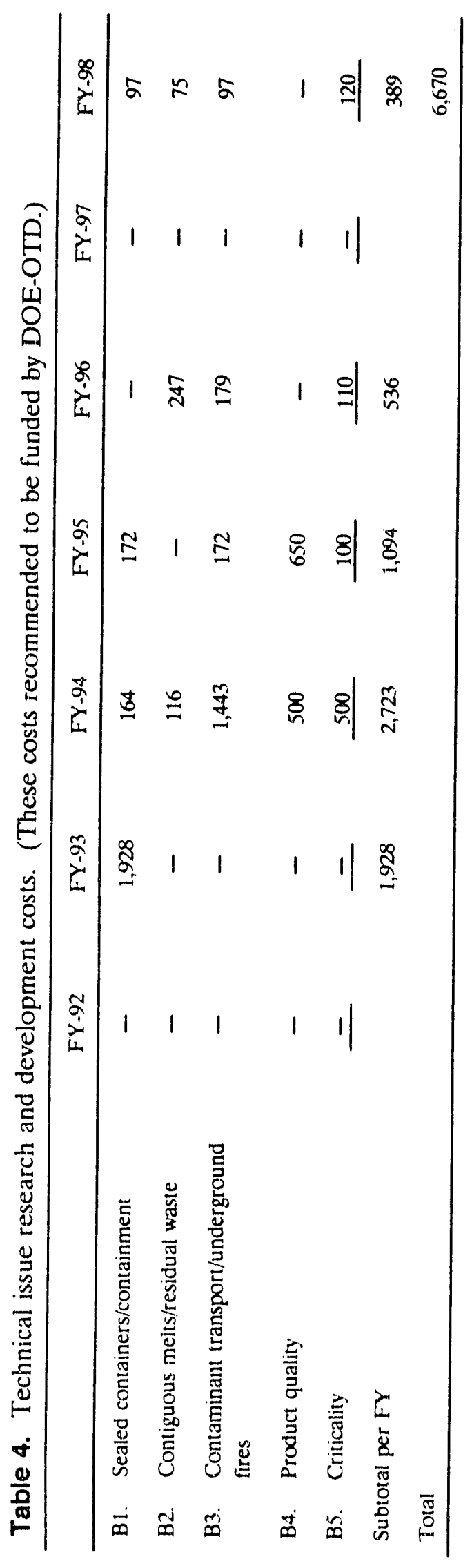




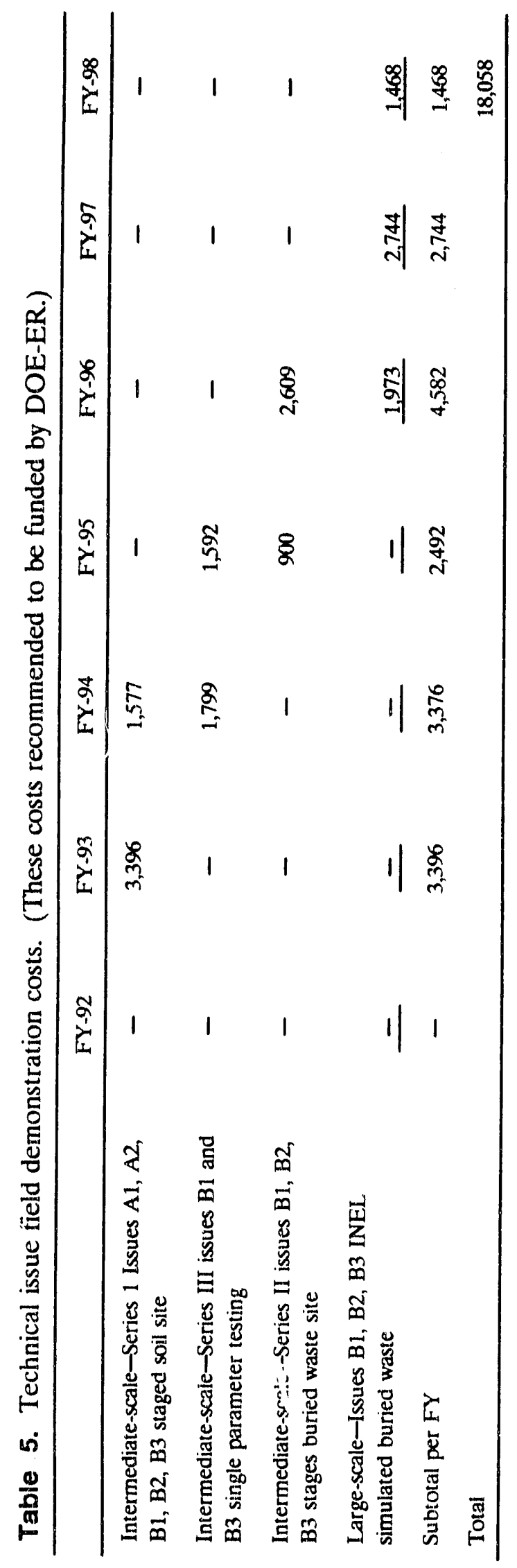




\section{Applied Research and Development Activity Description}

The following discussion outlines the scope of work currently envisioned for the applied R\&D issue resolution activities necessary to develop the ISV technology for buried waste applications. As is the case for the development of any technology in general, the scope of work for the described activities will be redefined as new information is obtained.

\section{Issue A1_Vapor Release from Unconfined Soils}

This issue involves the uncertainty regarding the behavior of gas and vapor movement, primarily steam, through and around the ISV melt during processing in an unconfined soils application. The motive force for gas movement is suspected to be due to both a slight pressure in the soil bencalh the melt and a vacuum extraction mechanism created by the sligh. negative pressure maintained in the containment hood covering the melt. Experience with confined or constricted situations indicates that for the ISV system, which is currently designed for contaminated soil applications, these situations lead to gas dynamics in the melt which ultimately result in significant quantities of molten soil being ejected from the melt. Although testing to date does not indicate that processing of unconfined soils will lead to similar molten soil ejection events, there is a need to qualify this empirical evidence with developed scientific tools.

Applied R\&D activities needed for resolution of this issue include the use of existing data, design of new experiments, and analytical modeling. This issue will be considered closed when the understanding of the gas release phenomenon and hood performance is sulficient to define the appropriate limits for the ISV technology. In addition, this understanding will assist in the design of new eontainment hoods and attendant equipment that will increase the ISV operating envelope.

\section{Issued A2-Fate of VOCs}

To successfully apply ISV to a given site, the transport of each subsurface volatile contaminant (mainly volatile organic compounds) during processing must be understood. Though migration away from the melt has not been observed to any significant extent for volatile contaminants and has not been observed for nonvolatile and semi-volatile contaminants, it is necessary to develop an understanding of this issue to determine if processing limits or other operational controls (e.g., overmelting) are needed for applications involving volatile species (i.e., contaminants with significant valpor pressures at or below $1000^{\circ} \mathrm{C}$ ). If significant quantities of material migrate away from the melt into surrounding soils, the waste may not be effectively treated or workers could be potentially harmed. In addition, such migration may require further remedial actions other than ISV (e.g., retricval of untreated contaminated soil).

The applied R\&D activities for resolution of this technical issuc focus on evaluating the variables which may alfect the movement of volatile contaminants. Examples of these variables include soil type and heterogeneity (e.g., porous regions of higher porosity than soil such as gravel beds), melt/soil thermal gradients, contaminant properties, power input, and off-gas containment hood vacuums. Activities include analytical studies to determine the fundamental mechanisms, development of predictive capabilities that account for subsurface heterogeneities, the identificalion of needed lest data, and the identification of laboratory and field monitoring instrumentation to collect test data. 


\section{Issue A4-Depth and Melt Shape Control}

The nature of the geometric evolution of the ISV melt is a critical part of the ISV process. Most important, the final melt shape and depth must be accurately known in order to ensure that the targeted waste has been incorporated into the melt. Monitoring of the geometry of an ongoing melt is also important in order to control the melt shape relative to the targeted waste zone. In addition to melt shape, depth is also an important aspect of the ISV process. The maximum currently demonstrated depth for a large-scale ISV system is approximately $5 \mathrm{~m}$. To realize the full potential of ISV as a remedial action technology, the demonstrated depth needs to be increased to approximately $10 \mathrm{~m}$.

Applied R\&D activities to resolve this technical issue will first be focused on information from past tests (e.g., progressive and final melt shape, progressive and final depth, field instrumentation utilized). Further efforts needed to resolve this issue are the development of predictive capabilities, development of control techniques (engineered solutions and operational changes), and refinement of field monitoring instrumentation for melt shape and depth.

\section{Issue A5-Product Quality}

In order to ensure the regulatory acceptability and verify the long-term performance of the ISV waste form, there is a need to assemble and communicate the vast amount of current data and understandings of the durability and performance of the ISV product and similar waste forms. The evaluation needs to take advantage of not only past ISV studies and datü, but relevant studies and data collected on similar waste forms, including those studies being performed by other Integrated Programs and Demonstrations. This information shall be communicated in a form useable by the regulators and end user of the ISV technology to aid in their technology evaluation, selection, and remedial design activities. The ultimate goal for resolution of this technical issue is to gain regulatory acceptance for the ISV final product.

Applied R\&D activities to develop the tools to predict long-term ISV product quality include the collection of ISV product data from past tests, evaluation of currently utilized product performance tests, development of product performance tests, development of criteria to evaluate long-term performance, and evaluation of alternative waste forms.

\section{Issue B1-Sealed Containers/Containment}

Experience with the advanced ISV application to buried waste indicates that the processing of buried waste is more dynamic relative to processing of unconfined soils. Transient pressurc and temperature spikes have been observed during field-scale testing, with the most significant transient leading to the ejection of molten soil from the melt. The underlying mechanism for these transient events is believed to be connected to the presence of sealed containers (e.g., drums). As the sealed container is thermally affected by the ISV melt, the pressure within the sealed container increases. A sudden release of this pressurized gas can lead to bubble formation in the ISV melt which ultimately results in transient events in the off-gas containment hood. These transient events are undesirabie for they have the potential to lead to untreated releases of material to the environment. 
Applied R\&D activities to rusolve this technical issue focus on the development of a lundamental understanding of the mechanisms leading to transient events. The fundamental understanding of this buried waste issue will build upon the understanding developed for the issue of vapor release from unconfined soils. Parameters of interest for this buried waste issue include container integrity, temperature and pressure pronile inside a container, pressure and temperature profile in the soil, effect of ISV melt volume and surlace area, and gas release rate into the off-gas containment hood. Fundamental engineering calculations supported by enginecring-scale test results are likely to provide the basis for the development of predictive tools for the application of ISV to buried waste. However, verification of the developed predictive tools will require field data from the intermediate- and large-scale units due to scaling relationships.

\section{Issue B2-Contiguous Melts/Residual Waste}

Due to the heterogeneous nature of buried waste (both in waste type and presence of void spaces) it is possible that the shape of the ISV melt would be other than the traditional tear-dropped shape observed for contaminated soil applications. If this hypothesis is accurate, then control of the ISV melt shape to form contiguous melts and eliminate unprocessed residual waste needs to be addressed. This issue may be considered closed when the operational parameters are identified such that a contiguous ISV block is formed from multiple melts and residual waste eliminated.

Research and development activities necessary to resolve this technical issue will build extensively upon the work performed for the contaminated soil technical issue of depth and melt shape control. The predictive tools for the vitrification of contaminated soils will be modified to account for the buried waste inhomogeneities, field monitoring equipment modified for buried waste, engineering solutions modified for buried waste, and adaptation of operating procedures modified for buricd waste applications.

\section{Issue B3-Contaminant Migration/Underground Fires}

As with the contaminated soil issue regarding the fate of VOCs, the concern is the movement of contaminants (e.g., volatile organics) into the surrounding soil and/or adjacent buried waste regions. The increased void spaces present in buried waste and the potential added driving force from gas releases from sealed containers are additional variables specific to buried waste and not present for soils. In addition, the inhomogeneous buried waste composition (combined with the potential for contarninant migration) increases the potential for underground fires. The source of oxygen for these fires would likely be from the thermal decomposition of compounds such as nitrates.

Activities for resolution of this technical issuc will be similar to those for the resolution of the fate of VOCs contaminated soil issue. Predictive tools developed for the resolution of the fate of V'OCs will be modified to account for the added void spaces, the waste site inhomogeneities, and the potential for chemical reactions (both inside and outside of sealed containers). Field monitoring equipment will be modified to account for the potentially higher gas velocities and to monitor for underground fires. 


\section{Issue B4-Product Quality}

This issue is identical to that identified for contaminated soils except for the increased metal fraction and other special case waste forms (e.g., concrete) expected for buried waste (from drums and disposed equipment). The predictive tools and tests developed for soil applications will be reevaluated and modified to account for the increased fraction of metal in the linal block and the potential for a metal phase below the ISV block.

\section{Issue B5-Criticality}

For some buried waste sites, there is the potential that the quantities of fissile materials is sufficient for a criticality to occur during IS $*$ processing. Mechanisms that can contribute to the concentration of fissile materials include: insolubility and pooling of the lissile materials in the ISV glass, densification of fissile materials prior to melt encapsulation, and entrainment and resulting condensation on the off-gas containment hood or in the off-gas treatment system.

The strong convestive mixing characteristic of the ISV process, as well as the solubility of plutonium oxide in the molten soil, indicate that any concentration of fissile materials is unlikely. Research and development activities will focus on verifying these assumptions via engineering calculations, engineering-scale tests with plutonium stimulants, and the identification of instrumentation to characterize the ISV melt (c.g., convective currents, chemical environment).

\section{Field-Scale Activity Description}

The following discussion outlines the scope of work currently envisioned for the field-scale activities necessary to develop the ISV technology for buried waste applications. These lield-scale activities provide the field data for verification of the applied R\&D predictive tools. As is the case for the development of any technology in general, the scope of work for the described activities will be redefined as new information is obtained.

\section{Intermediate-Scale Series I}

This series consists of a single field-scale test on a staged soil site that provides the data to resolve the issues of vapor release from unconfined soils and the fate of VOCs. In addition, data collected will be used to continue evaluating the merits of continued development efforts for buried wasie applications. Data which will be used in the decision to proceed with buricd waste development efforts include resolution of the above contaminated soil issues, successful characterization techniques (e.g., porosity, permeability, moisture content), successful field monitoring (c.g., contaminant concertrations, gas movement, soil pressures), and the characterization of the offgas containment system (c.g., material and energy balance). The data collected for the decision point provides the baseline data for soils for which data collected for buried waste will be compared to.

\section{Intermediate-Scale Series II}

This series is envisioned to be composed of two separately staged buried waste sites. The first staged site is to be designed to gather the fundamental data for applying ISV 10 sealed containers and will consist of individually instrumented containers spaced such that the separate effects from each 
container can be studied. Parameters of interest include the temperature and pressure profiles in the container, in the soil, and in the off-gas containment hood; process variables such as power input and melt rate; melt volume and surface area; and rate of gas telease into the off-gas containment system. The results from this test will provide a first level verification of developed predictive tools and dictate if operational and/or equipment modifications are needed for the second staged buried waste sile.

The second staged buried waste site will be staged to simulate a typical INEL buried waste site. A similar staging was performed in 1990; however, the understanding of the buried waste issues was not such to adequately instrument the site and gather the data necessary 10 resolve the issues. In addition, the objective for the 1990 ficld-scale tests was to evaluate the feasibility of ISV for buricd waste applications. The second staged site of Intermediate-Scale Serics II will build upon the knowledge gained from the 1990) tests, the applied R\&D efforts for buried waste, and the results from the first staged buried waste site of this series. Fotential operational changes include slower processing rates, additional suppression sys:ems, and processing from depth to grade. Potential equipment modifications include design of secondary containment and utilization of pretreatment technologies to compromise the integrity of sealed containers.

\section{Large-Scale Burled Waste Demonstration}

This large-scale demonstration of the ISV techrology on a simulated buricd waste site, or sites, will provide the final field data to close the technical issues associated with buried waste. The data from a full-scale unit is needed due to the scalability issue between waste stimulants at the intermediate-scale and the actual buried waste. For example, it is unclear whether the gas release mechanism from a 55-gallon drum is the same as that for a 2.5 -gallon drum (scaled representation of a 55 -gallon drum used in intermediate-scale tests). In addition, to fully support the Remedial Investigation/Feasibility Study Report, the ISV iechnology must provide data representative of fulfscale application.

\section{Technology Transfer Plan}

The goal of the ISV technology transfer plan is to (a) provide the strategy for transferring ISV lechnology to DOE customers, (b) provide the irnplementation activities necessary to conduct a successful technology transfer program, (c) identily the roles and responsibilities of the principal players involved with transferring the technology, and (d) identify funding responsibilities for technology transfer and related activities. The desired end result is to facilitate the technology transfer process for ISV and get the technology applied to those sites where significant needs exist. The complete technology transfer plan, as developed by the ISV Integrated Program, is in Appendix C.

Three major strategic elements eomprise the technology transter plan:

- Technical Outrach-Enhance the recognition ol ISV's capabilities lor resolving specific and general problems lacing DOE

- Information Exchange-ldentily specific activities that need to be performed to successfully implement ISV into the customer's waste site plans 
- Technical Assistance and Collaboration-Continued technical assistance by ISV technology development staff throughout the resolution of issues and implementation stages.

This ISV Technology Development Plan for Buried Waste Applications document and the coordination of ISV staff at the INEL and PNL to produce it comprise the first two elements of the technology transfer plan. The initiation of activities to resolve technical issues is needed to begin the third element of the technology transfer plan.

The key for the successful transfer of the ISV technology from a development phase to an application phase is the coordination and cooperation of the participants. For buried waste applications, these participants are the PNL ISV staff, EG\&G Idaho ISV staff, ISV-IP, staff from the Buried Waste Integrated Demonstration (BWID), EG\&G Idaho ER staff, and DOE-ID ER staff. The development of the ISV technology for buried waste applications requires the integration of these participants for the resolution of technical issues and potential programmatic issues. 


\section{REFERENCES}

1. U.S. Congress, Office of Technology Assessment, Complex Cleanup: The Environmental Legacy of Nuclear Weapons Production, OTA-O-484, Washington D.C.: U.S. Government Printing Office, February 1991.

2. J. L. Mayberry, W. J. Quapp, F. Feizollahi, and J. C. Del Signore, Preliminary Systems Design Study Assessment Report, EG\&G Idaho, Inc., EGG-WTD-9594, Vols 1 - 8, Idaho National Engincering Laboratory, 1991.

3. K. H. Oma, M. A. H. Rcimus, C. L. Timmerman, Support for the In Situ Vitrification Treatability Study at the Idaho National Engineering Laboratory: FY 1988 Summary, Pacific Northwest Laboratory, PNL-6787, February 1989.

4. R. A. Callow, L. E. Thompson, J. R. Weidner, C. A. Loehr, B. P. McGrail, S. O. Bates, In Situ Vitrification Application to Buried Waste: Final Report of Intermediane Field Tests at Idaho National Engineering Laboratory, EG\&G Idaho, Inc., EGG-WTD-9807, August 1991.

5. H. D. Nguyen, APOLLO: A Computer Program for the Calculation of Chemical Equilibrium and Reaction Kinetics of Chemical Systems, EG\&G Idaho, Inc., EGG-WTD-9876, September 1991.

6. P. R. McHugh, J. D. Ramshaw, A Computational Model for Viscous Fluid Flow, Heat Transfer; and Melting in In Situ Virrification Melt Pools, EG\&G Idaho, Inc., EGG-WTD-9845, Octother 1991 .

7. P. E. Murray, M. O. Fryer, Simulation of Heat Conduction and Electric: Fields During In Situ Vitrification of Soil: Methods Design and Verification, EG\&G Idaho, Inc., EGG-WM-S(1)45, September 1990.

8. J. L. Buelt, C. L. Timmerman, K. H. Oma, V. F. Fitzpatrick, J. G. Carter, In Silu Virrification of Transuranic Waste: An Updated Systems Evaluation and Applications Assessment, Pacific Northwest Lathoratory, PNL-4800 Supplement 1, March 1987.

9. R. Schlueter, J. J. Schafer, Low-Level and Transuranic Waste Transpontation, Disposal, and Facility Decommissioning Cost Sensitivity Analysis, EG\&G Idaho, Inc., EGG-WTD-1(K)92, June 1992.

10. C. M. Stoxts et al. Technical lssues Associated with In Situ Vitrification of the INEL Subsurface Disposal Arca, Volume I: A Systematic Approach for Identification, Prioritization, and Closure of Technical Issues, EG\&G ldaho, Inc., EGG.WTD.y985, December 1אyl. 


\begin{abstract}
Appendix A
In Situ Vitrification Technology Development Logic Diagram
\end{abstract}


A-2 


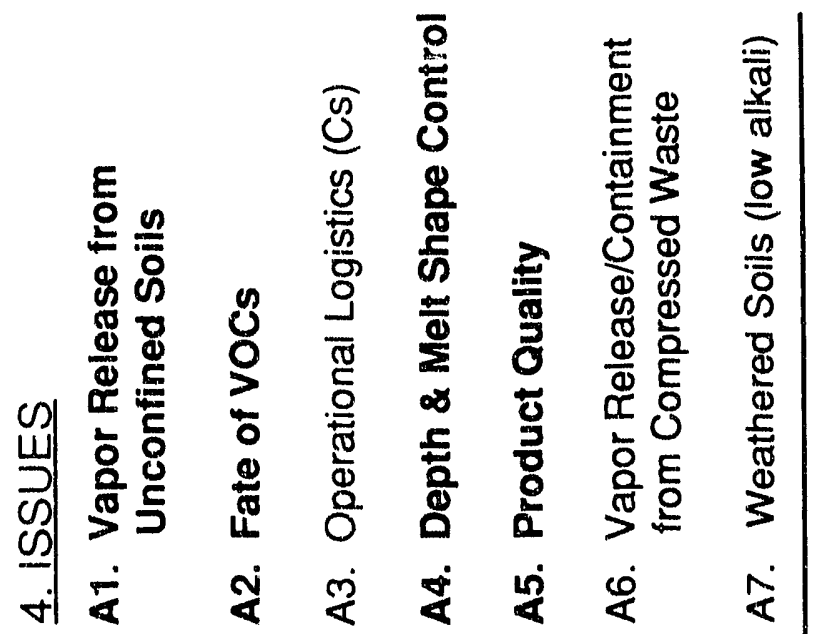

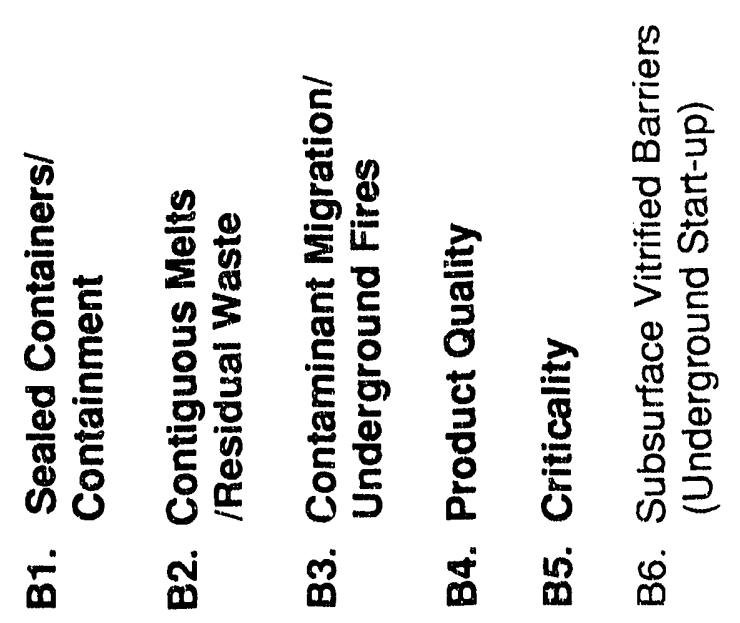

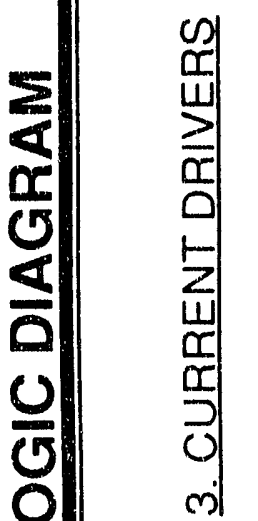

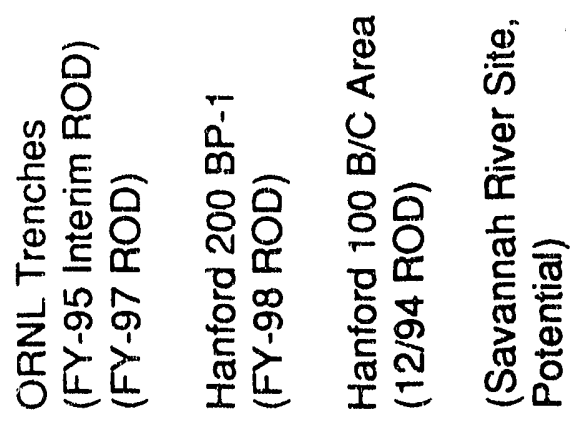

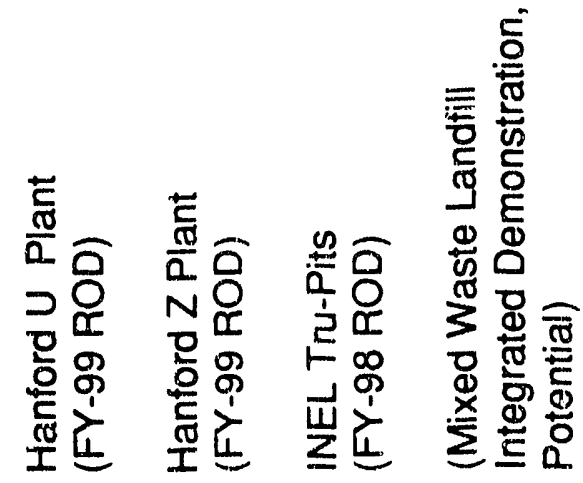

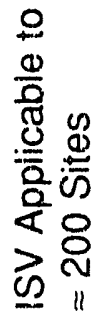

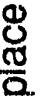

되

离

芛 苗

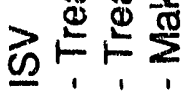

0

$0.1 \frac{\omega}{5}$

$\frac{2}{3} \quad$ i

U.

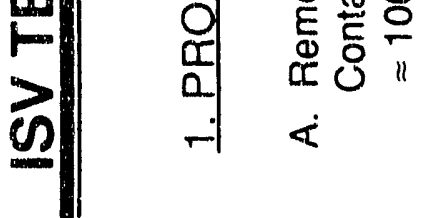

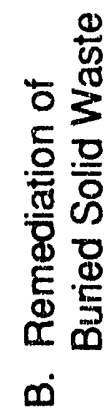




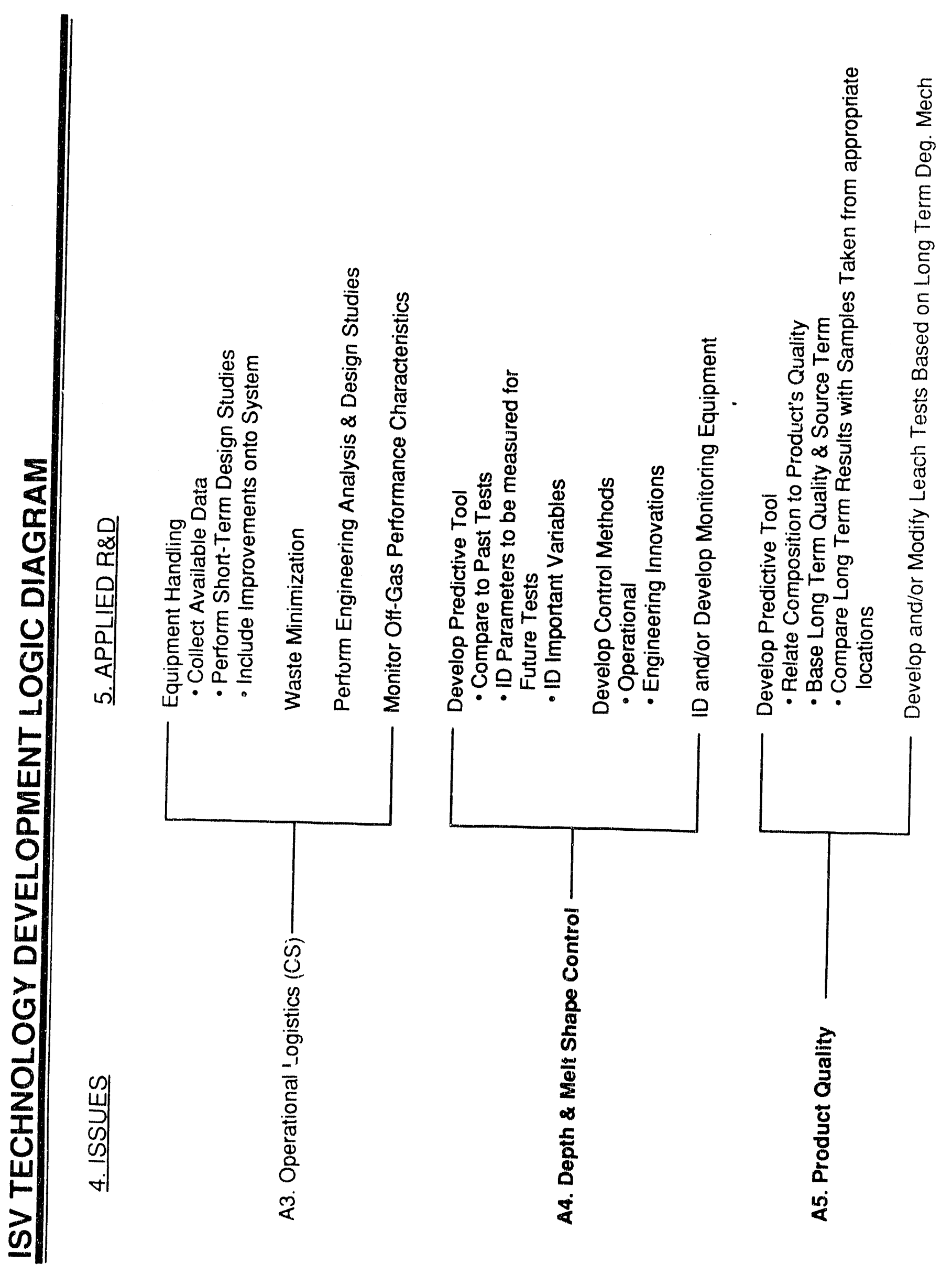


-

言

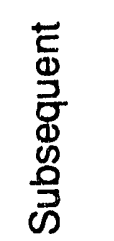

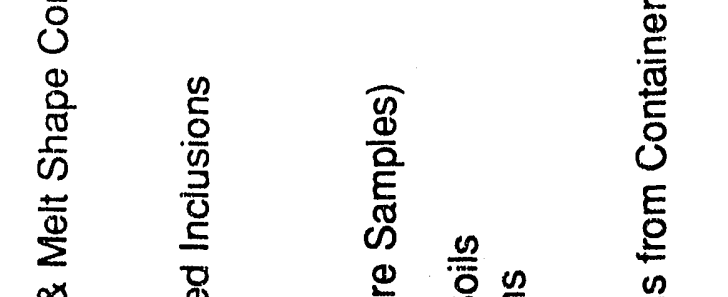

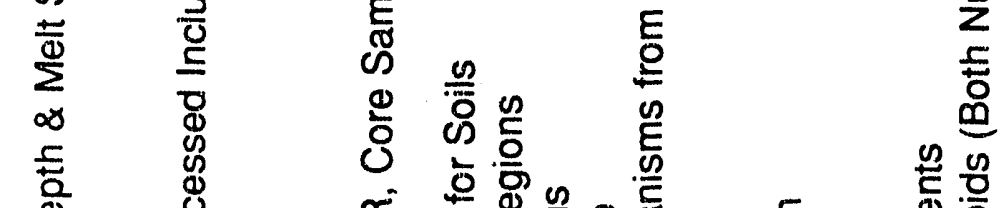

各 $\quad$ o

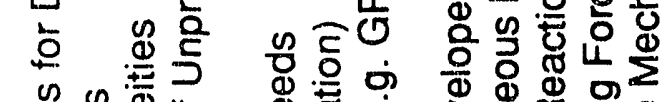

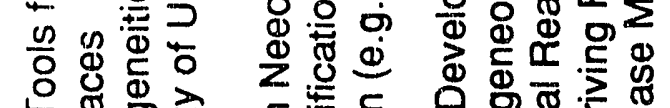
$1-8$

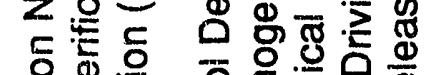

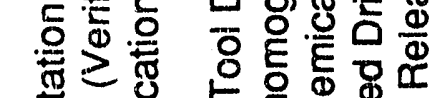

ஸे

语 응 은

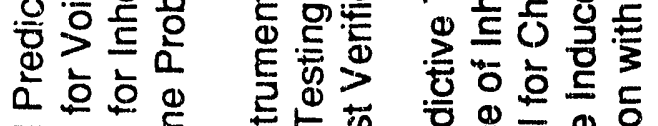

는ํㄴ은

点范

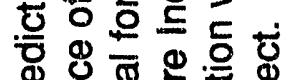

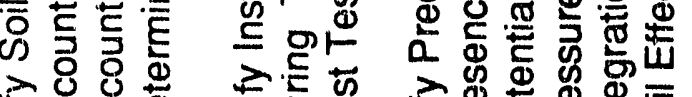

:

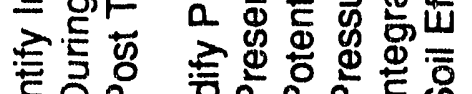

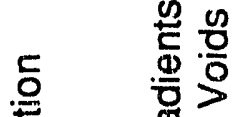

党

है 동 敢

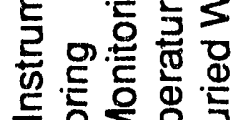

드 흥을 을

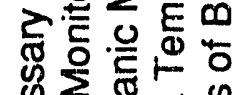

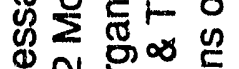

\&O 乙约

舟导

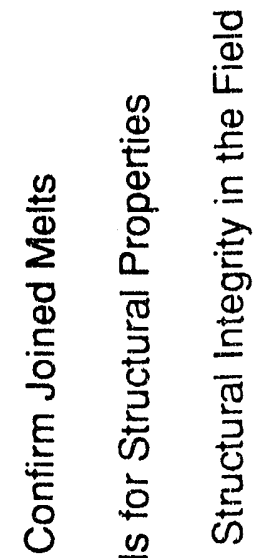

ऊक ब

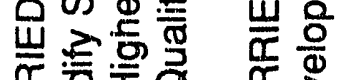

일

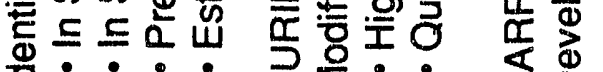

웜

$\infty \sum$ 四 D

$z_{11}$
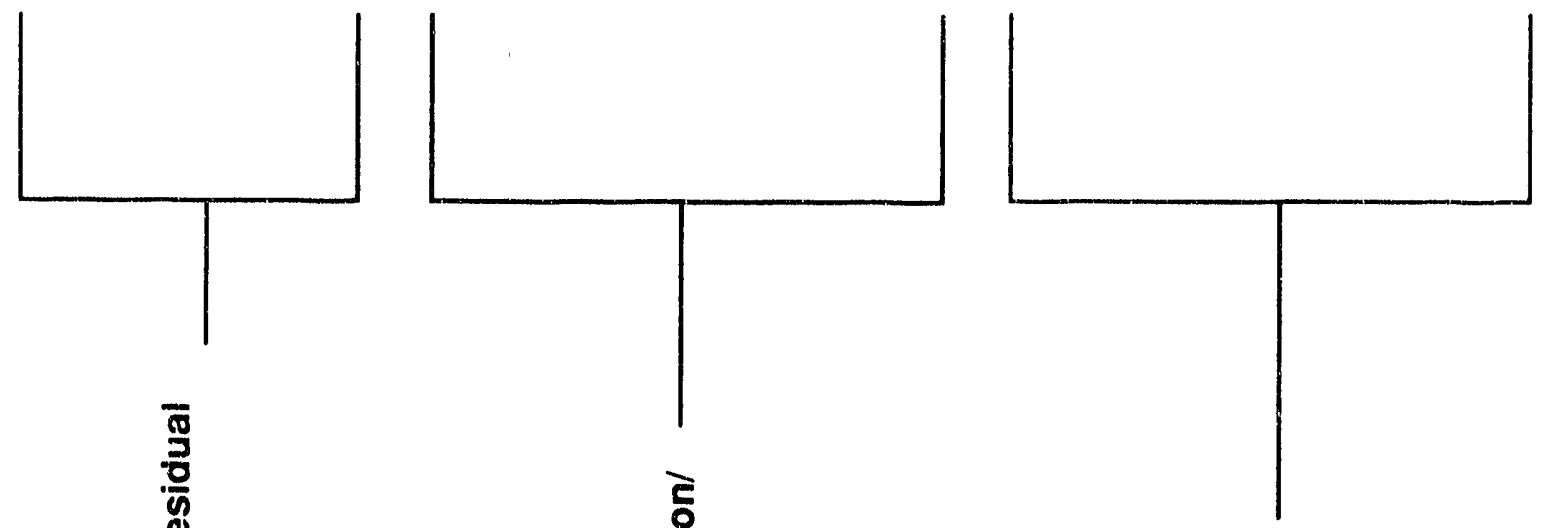

ڤึ)

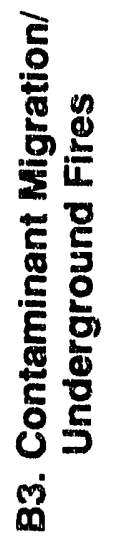

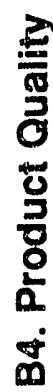




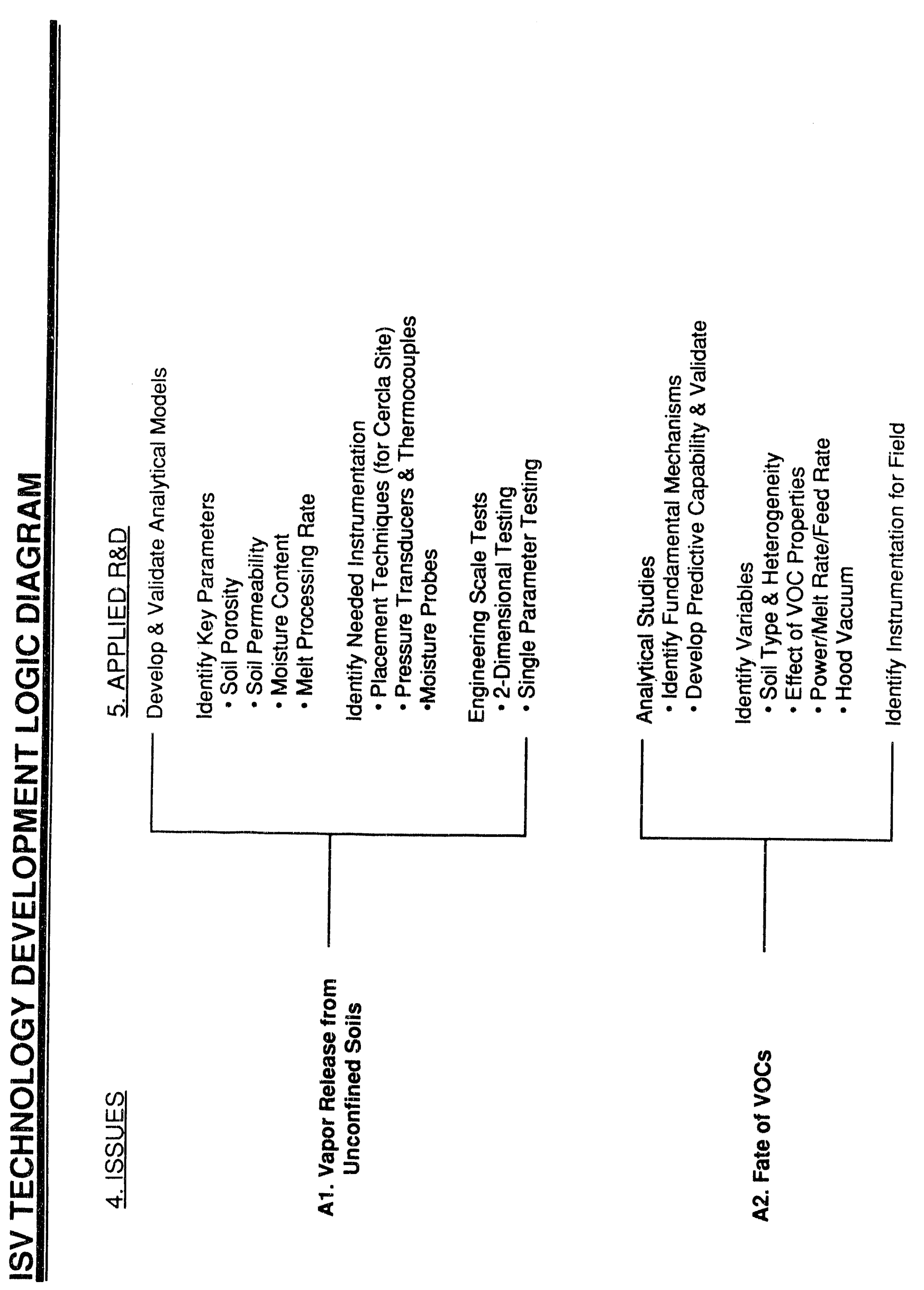




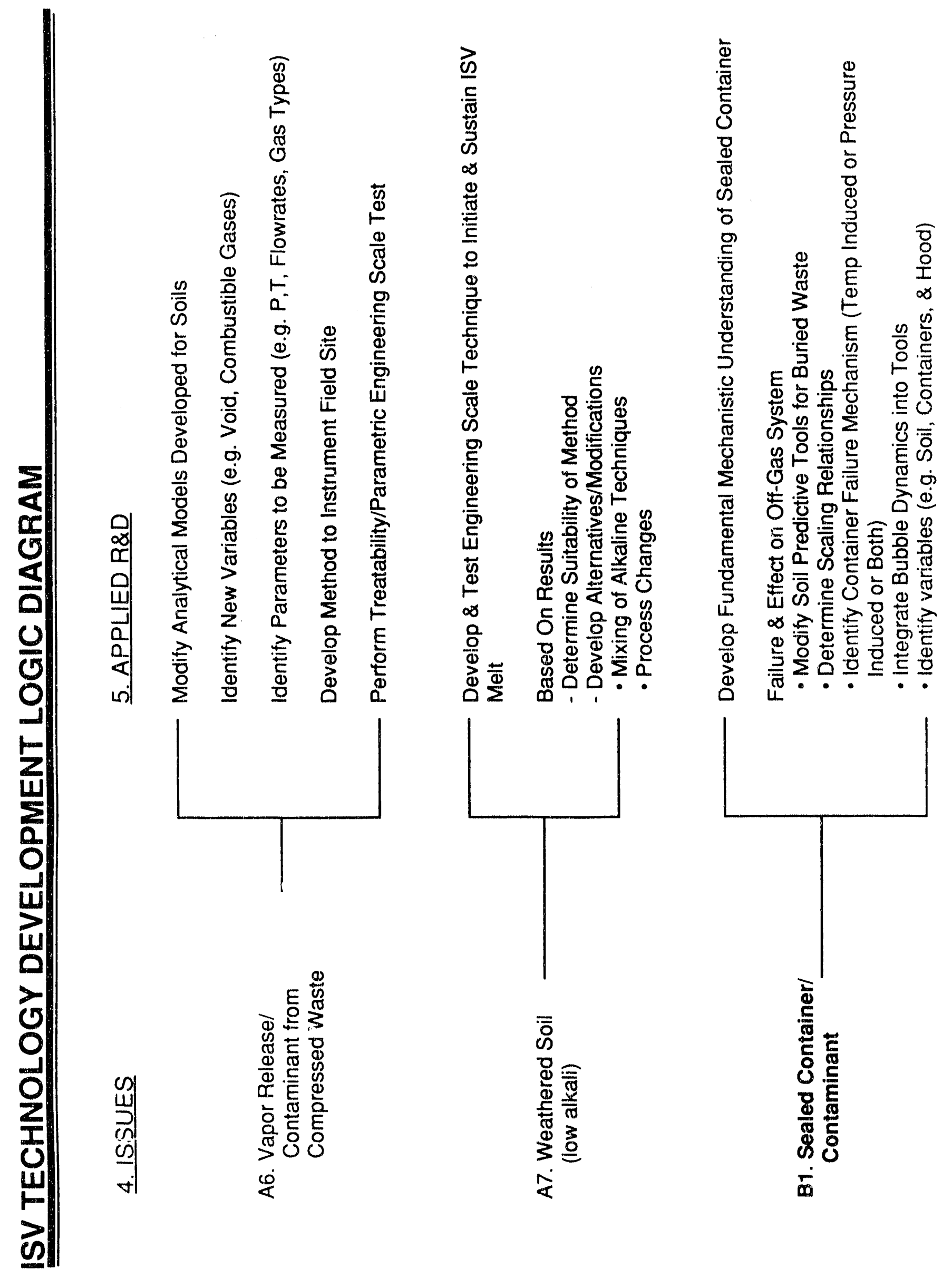




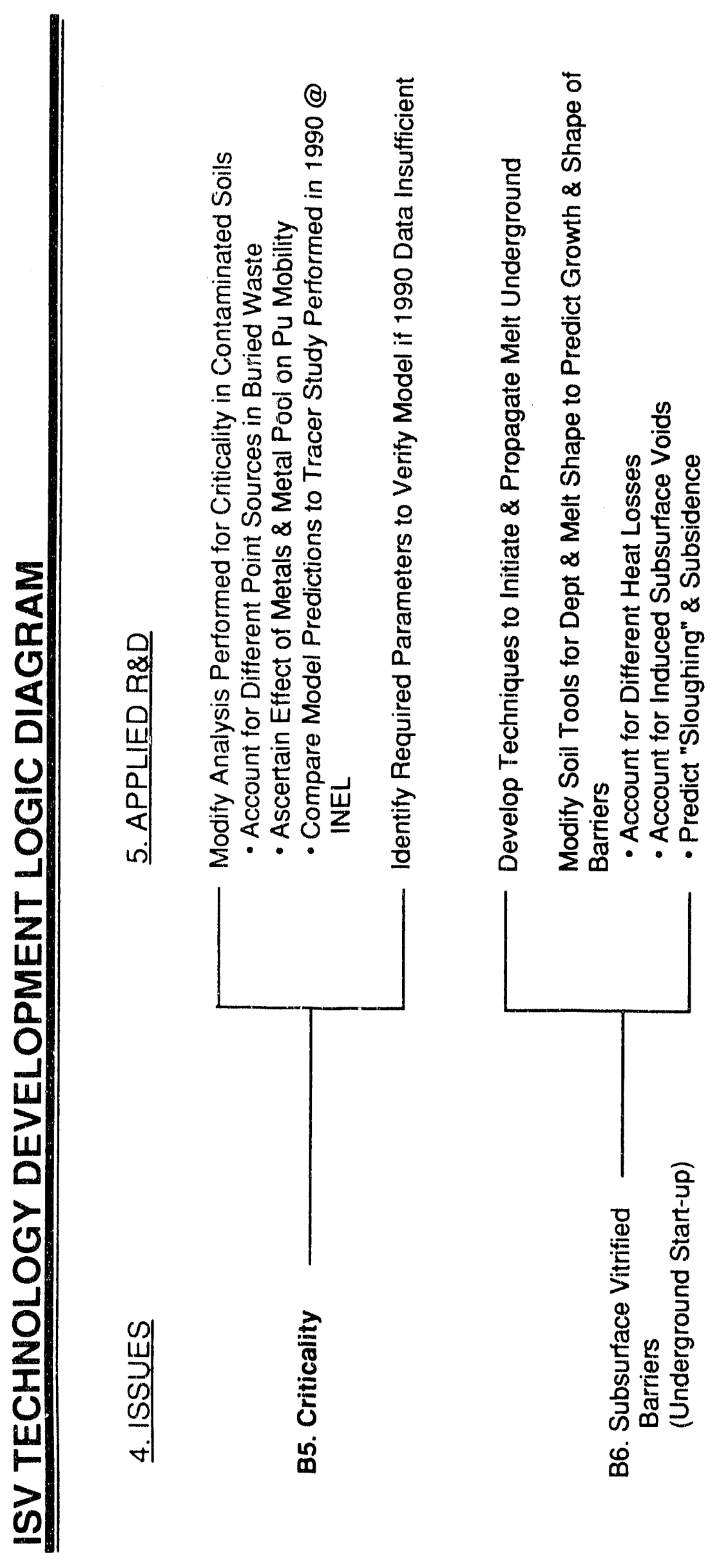




\section{Appendix B}

Budget Basis for Activities Needed for the Development of the In Situ Vitrification Technology for Buried Waste Applications 


\title{
Appendix B
}

\section{Budget Basis for Activities Needed for the Development of the In Situ Vitrification Technology for Buried Waste Applications}

\author{
ACTIVITY: RESOLUTION OF CONTAMINATED SOIL ISSUE \\ A1. VAPOR RELEASE FORM UNCONFINED SOILS
}

\section{DESCRIPTION}

Applied research and development activities needed for resolution of this issue include the use of existing data, design of new experiments, and analytical modeling. This issue will be considered closed when the understanding of the gas release phenomenon and hood performance is sufficient to design containment hoods and attendatit equipment that will limit and releases of radioactive or hazardous materials to acceptable limits. Acceptable limits for release are defined as those releases that do not compromise Environmental, Safety, and Health (ES\&H) concerns and are in compliance with appropriate regulations.

\section{BUDGET BASIS}

In FY-91, the ISV Integrated Program (ISV-IP) identilied the issue of vapor release from unconfined soils as one to be resolved by the ISV-IP in FY-92. The ISV-IP Technical Support Groups (TSGs) reviewed submitted Technical Task Plans (TTPs) and selected those for funding via the ISV-IP which would close the ISV technical issue. Lack of ISV-IP lunding for FY-92 has delayed the resolution of this technical issue into FY-93.

The budget for resolution of this technical issue is from the TTPs identified by the ISV-IP. Detailed breakdown of the identified budget by task may be found in the TTPs selected by the ISV-IP.

FY-93 BUDGET \$1462.0K

FY-94 BUDGET $\$ 784.0 \mathrm{~K}$

ACTIVITY TOTAL $\$ 2246.0 \mathrm{~K}$ 


\section{ACTIVITY: RESOLUTION OF CONTAMINATED SOIL ISSUE} A2. Fate of VOCs

\section{DESCRIPTION}

The applied R\&D activities for resolution of this technical issue focus on evaluating the variables which may affect the movement of vr'atile contaminants. Examples of these variables include soil type and heterogeneity (e.g., porous regions of higher porosity than soil such as gravel beds), meit/soil thermal gradients, contaminant properties, power input and off-gas containment hood vacuum. Activities include analytical studies to determine the fundamental mechanisms, development of predictive capabilities that account for subsurface heterogeneities, identification of needed test data, and identification of laboratory and field monitoring instrumentation to collect test data.

\section{BUDGET BASIS}

In FY-91, the ISV Integrated Program (ISV-IP) identified the fate of volatile organic compounds (VOCs) during ISV processing as one to be resolved by the ISV-IP in FY-92. The ISV-IP Technical Suppurt Groups (TSGs) reviewed submitted Technical Task Plans (TTPs) and selected those for funding via the ISV-IP which would close the ISV technical issuc. Lack of ISV-IP funding for FY-92 has delayed the resolution of this technical issue into FY-93.

The budget for resolution of this technical issue is from the TrTs identified by the ISV-IP. Detailed breakdown of the identified budget by task may be found in the TTPs selected by the ISV-IP.
FY-93 BUDGET
$\$ 724.0 \mathrm{~K}$
FY-94 BUDGET
$\$ 441.0 \mathrm{~K}$
ACTIVITY TOTAL $\$ 1165.0 \mathrm{~K}$ 


\section{ACTIVITY: RESOLUTION OF CONTAMINATED SOIL ISSUE}

\section{A4. DEPTH AND MELT SHAPE CONTROL}

\section{DESCRIPTION}

Applied R\&D activities to resolve this technical issue will first be locused on information from past tests (e.g., progressive and final melt shape, progressive and final depth, lield instrumentation utilized). Further efforts needed to resolve this issue is the development of predictive capabilities, development of control techniques (engineered solutions and operational changes), and refinement of field monitoring instrumentation for melt shape and depth. Particular parameters which should be well known prior to processing of contaminated soil sites include density, porosity, permcability, and composition and moisture content of soil to be processed.

\section{BUDGET BASIS}

In FY-91, the ISV Integrated Program (ISV-IP) identified the issue of depth and melt shape control as one to be resolved by the ISV-IP in FY-92. The ISV-IP Technical Support Groups (TSGs) reviewed submitted Technical Task Plans (TTPs) and selected those for funding via the ISV-IP which would close the ISV technical issue. Lack of ISV-IP funding for FY-92 has delayed the resolution of this technical issue into FY-93.

The budget for resolution of this technical issue is from the TTPs identified by the ISV-IP. Detailed breakdown of the identified budget by task may be found in the TTPs selected by the ISV-IP.

$\begin{array}{ll}\text { FY-93 BUDGET } & \$ 1229.0 \mathrm{~K} \\ \text { FY.94 BUDGET } & \$ 662.0 \mathrm{~K} \\ \text { ACTIVITY TOTAL } & \$ 1891.0 \mathrm{~K}\end{array}$




\section{ACTIVITY: RESOLUTION OF CONTAMINATED SOIL ISSUE A5. PRODUCT QUALITY}

\section{DESCRIPTION}

In order to ensure the regulatory acceptability and the long term performance of the ISV waste form, there is a need to assemble and communicate the vast amount of current data and understandings of the durability and performance of the ISV product and similar waste forms. The information needs to take advantage of not only past ISV studies and data, but relevant studies and data collected on similar waste forms, including those studies being performed by other Integrated Programs and Demonstrations. This information shall be communicated in a form useable by the regulators and end user of the ISV technology to aid in their technology evaluation, selection, and remedial design activities. The ultimate goal for resolution of this technical issue is to gain regulatory acceptance for the ISV final product.

Applied R\&D activities to develop the desired end product include collection of ISV product data from past tests, evaluation of currently utilized product performance tests, development of product performance tests, development of criteria to evaluate long-term performance, and evaluation of alternative waste forms.

\section{BUDGET BASIS}

The ISV Integrated Program (ISV-IP) has identified the issue of product quality for resolution beginning in FY-94. A request for proposals has been made by the ISV-IP for FY-93. These proposals will be evaluated by the ISV-IP Technical Support Groups and Technical Task Plans requested for those proposals selected for funding by the ISV-IP.

The following budget has been requested by the ISV-IP for resolution of this technical issue.

$\begin{array}{ll}\text { FY.94 BUDGET } & \$ 500.0 \mathrm{~K} \\ \text { FY.95 BUDGET } & \$ 650.0 \mathrm{~K} \\ \text { ACTIVITY TOTAL } & \$ 1150.0 \mathrm{~K}\end{array}$




\section{ACTIVITY: RESOLUTION OF BURIED WASTE ISSUE B1: SEALED CONTAINER/CONTAINMENT}

\section{DESCRIP'TION}

Applied R\&D activities to resolve this technical issue focus on the development of a fundamental understanding of the mechanisms leading to transient events. The fundamental understanding of this buried waste issue will build upon the understanding developed for the issue of vapor release from unconfined soils. Parameters of interest for this buried waste issuc include container integrity, temperature and pressure profile inside a container, pressure and temperature profile in the soil, effect of ISV melt volume and surface area, and gas release rate into the off-gas containment hood. Fundamental engineering calculations supported by engineering-scale test results are likely to provide the basis for the development of predictive tools for the application of ISV to buried waste. However, verification of the developed predictive tools will require ficld data from the intermediate and large-scalc units due to scaling relationships.

\section{BUDGET AND PLANNING ASSUMPTIONS}

Budget and planning assumptions are (a) five percent per year escalation, (b) task starts October 1993, (c) OTD continues to fund Vapor Release issue study in 1993 (currently partially lunded), and (d) field demonstrations are funded and scheduled as planned to allow adequate task integration.

\section{BUDGET BASIS}

Costs were estimated for the individual tasks as defined below. Estimate basis: (a) labor estimates based on 3 years experience of code development for ISV process modeling, (b) enginecring-scale historical test costs at Geosafe and PNL, and (c) project support and management $(15 \%)$ based on 3 years experience.

\section{FY-93 BUDGET BREAKDOWN BY TASK}

Labor

Identify parameters common to contaminated soils and identify buried waste parameters $\quad 0.25$ FTE Modify soil tools Integrate bubble dynamics Analyze past data Engineering scale parametric tests Identify instrumentation Develop fundamental understanding Nonlabor

Project Management

TASK SUBTOTAL 1.00) FTE 4.37 FTE 0.50 FTE

$\$ 1606.7 \mathrm{~K}$

4.00 FTE

0.13 FTE

1.50 FTE

$\$ 70.0 \mathrm{~K}$

$\$ 251.5 \mathrm{~K}$

$\$ 1928.2 \mathrm{~K}$ 
FY-94 BUDGET BREAKDOWN BY TASK

Labor

Verify with IST-1 data

Develop criteria for IST-2

Nonlabor

Project Management

TASK SUBTOTAL

$0.50 \mathrm{FTE}$

$0.50 \mathrm{FTE}$

$\$ 0.0 \mathrm{~K}$

$\$ 21.4 \mathrm{~K}$

$\$ 164.4 \mathrm{~K}$

FY-95 BUDGET BREAKDOWN BY TASK

Labor

Verify with IST-2 data

$0.50 \mathrm{FTE}$

Develop criteria for full-scale

$0.50 \mathrm{FTE}$

Nonlabor

Project Management

TASK SUBTOTAL

FY-98 BUDGET BREAKDOWN BY TASK

Labor

Verify with full-scale data

Nonlabor

Project Management

TASK SUBTOTAL

$0.50 \mathrm{FTE}$

$\$ 84.4 \mathrm{~K}$

$0.0 \mathrm{~K}$
$22.4 \mathrm{~K}$

$\$ 171.9 \mathrm{~K}$

TOTAL TASK COST 


\section{ACTIVITY: RESOLUTION OF BURIED WASTE ISSUE B2: CONTIGUOUS MELT/RESIDUAL WASTE}

\section{DESCRIPTION}

Control of the ISV melt shape to form contiguous melts and eliminate unprocessed residual waste needs to be addressed. This issue may be considered closed when the operational parameters are identified such that a con.iguous ISV block is formed from multiple melts and residual waste eliminated.

Research and development activities necessary to resolve this technical issue will build extensively upon the work performed for the contaminated soil technical issue of depth and melt shape control. The predictive tools for the vitrification of contaminated soils will be modified to account for the buried waste inhomogeneities, field monitoring equipment modified for buried waste, engincering solutions modified for buried waste, and adaptation of operating procedures modified for buricd waste applications.

\section{BUDGET AND PLANNING ASSUMPTIONS}

Budget and planning assumptions are: (a) five percent per year escalation, (b) ISV-IP issue on depth and melt funded and resolved during FY-93 and FY-94 to allow adequate task integration, and (c) resolution of task requires interface with intermediate and large ISV field demonstrations.

\section{BUDGET BASIS}

Costs were estimated for the individual tasks as defined below. Estimated basis: (a) labor estimates based on 3 years experience of code development for ISV process modeling and (b) engineering-scale historical test costs at Geosafe and PNL, and (c) project support and management $(15 \%)$ based on 3 years experience.

\section{FY-94 BUDGET BREAKDOWN BY TASK}

Labor

Identify parameters common to contaminated soils

Identify variables

Modify soil predictive tools

Compare to past data

Identify instrumentation

Nonlabor

Project Management

$\$(0.0 \mathrm{~K}$

0.25 FTE

0.08 FTE

0.08 FTE

0.17 FTE

0.13 FTE

TASK SUBTOTAL

$\$ 15.2 \mathrm{~K}$

$\$ 116.4 \mathrm{~K}$

\section{FY-96 BUDGET BREAKDOWN BY TASK}

Labor

Verify with IST-2 data

0.75 FTE

$\$ 214.4 \mathrm{~K}$ 
Develop criteria for lull-scalc

Project Management

TASK SUBTOTAL

FY-98 BUDGET BREAKDOWN BY TASK

Labor

Verify with full-scale data

Nonlabor

Project Management

TASK SUBTOTAL

TOTAL TASK COST
0.75 FTE

$\$ 0.0 \mathrm{~K}$

$\$ 32.2 \mathrm{~K}$

$\$ 246.6 \mathrm{~K}$

$\$ 65.0 \mathrm{~K}$

0.50 FTE

$\$ 0.0 \mathrm{~K}$

$\$ 9.8 \mathrm{~K}$

$\$ 74.8 \mathrm{~K}$

$\$ 437.8 \mathrm{~K}$

B-10 


\section{ACTIVITY: RESOLUTION OF BURIED WASTE ISSUE B3: CONTAMINANT TRANSPORT \& UNDER GROUND FIRES}

\section{DESCRIPTION}

The concern of this issue is with the movement of contaminants (c.g., volatile organics) into the surrounding soil and/or adjacent buried waste regions. The increased void spaces present in buried waste and the potential added driving force from gas releases from sealed containers are additional variables specific to buried waste and not present for soils. In addition, the inhomogeneous buried waste composition (combined with the potential for contaminant migration) increases the potential for underground fires. The source of oxygen for these fires would likely be from the thermal decomposition of compounds such as nitrates.

Activities for resolution of this technical issue will be similar to those for the resolution of the fate of VOCs contaminated soil issue. Predictive tools developed for the resolution of the fate of VOCs will be modified to account for the added void spaces, the waste site inhomogeneities, and the potential for chemical reactions (both inside and outside of sealed containers). Field monitoring equipment will be modified to account for the potentially higher gas velocities and to monitor for underground fires.

\section{BUDGET AND PLANNING ASSUMPTIONS}

Budget and planning assumptions are: (a) five pereent per year escalation, (b) schedule assumes ISV-IP makes adequate progress in FY-93 on contaminant migration in soils to allow transfer of information in timely fashion, and (c) task funding/schedule must also integrate with intermediate and large ISV field demonstrations.

\section{BUDGET BASIS}

Costs were estimated for the individual tasks as defined below. Estimate basis: (a) labor estimates based on 3 years experience of code development for ISV process modeling, (b) engineering-scale test costs at Geosale and PNL, and (c) project support and management (15\%), based on 3 years experience.

\section{FY-94 BUDGET BREAKDOWN BY TASK}

Labor

Identify parameters common to contaminated soils

Identify key parameters

Modify soil tools

Enginecring scale parametric

tests

Identify instrumentation

Evaluate with enginecring-scale data
$\$ 1104.9 \mathrm{~K}$

0.25 FTE

0.25 FTE

1.50 FTE

4.00 FTE

0.13 FTE

1.50 FTE 
Nonlabor

Project Management

$\$ 150.0 \mathrm{~K}$

$\$ 188.2 \mathrm{~K}$

TASK SUBTOTAL

$\$ 1443.2 \mathrm{~K}$

FY-95 BUDGET BREAKDOWN BY TASK

Labor

Verify with IST-1 data

Develop criteria for IST-2

Nonlabor

Project Management

TASK SUBTOTAL

$\begin{array}{ll}0.50 \mathrm{FTE} & \$ 149.5 \mathrm{~K} \\ 0.50 \mathrm{FTE} & \\ & \$ 0.0 \mathrm{~K} \\ & \$ 22.4 \mathrm{~K} \\ & \$ 171.9 \mathrm{~K}\end{array}$

FY-96 BUDGET BREAKDOWN BY TASK

Labor

Verify with IST-2 data

Nonlabor

Develop criteria for full-scale

0.50 FTE

$\$ 156.0 \mathrm{~K}$

0.50 FTE

$\$ 0.0 \mathrm{~K}$

$\$ 2.4 \mathrm{~K}$

$\$ 179.4 \mathrm{~K}$

FY.98 BUDGET BREAKDOWN BY TASK

Labor

Verify with full-scale

Nonlabor

0.50 FTE

$\$ 84.5 \mathrm{~K}$

Project Management

TASK SUBTOTAL

TOTAL TASK COST

$\$ 0.0 \mathrm{~K}$

$\$ 12.7 \mathrm{~K}$

$\$ 97.1 \mathrm{~K}$

$\$ 1891.5 \mathrm{~K}$ 


\section{ACTIVITY: RESOLUTION OF BURIED WASTE ISSUE B4. PRODUCT QUALITY}

\section{DESCRIPTION}

In order to ensure the regulatory acceptability and the long-term performance of the ISV waste form, there is a need to assemble and communicate the vast amount of current data and understandings of the durability and perlormance of the ISV product and similar waste forms. The information needs to take advantage of not only past ISV studies and data, but relevant studies and data collected on similar waste forms, including those studies being performed by other integrated programs and demonstrations. This information shall be communicated in a form useable by the regulators and end user of the ISV technology to aid in their technology cvaluation, selection, and remedial design activities. The ultimate goal for resolution of this technical issue is to gain regulatory acceptance for the ISV final product.

Applied R\&D activities to resolve this buried waste technical issue will build upon those activities performed to resolve the contaminated soil technical issue of product quality. Specifically, the product quality R\&D activities for this buried waste technical issue will include collection of ISV product data from past tests with buried waste, evaluate performance of a metal phase (if formed), modify product performance tests for buried waste, and reevaluate criteria to evaluate long-term performance.

\section{BUDGET BASIS}

The issue of product quality of the ISV wasteform for buried waste applications is to be resolved in parallel with resolution of the issue of product quality for contaminated soil applications. The ISV Integrated Program (ISV-IP) has identified the issue of product quality for contaminated soil applications for resolution beginning in FY.94.

The following budget is based on that requested by the ISV-IP for resolution of the product quality issue for contaminated soil applications. A separate call for proposals may be issued for the issue of product quality for buried waste applications or modifications made to Technical Task Plans identified by the ISV-IP.

$\begin{array}{ll}\text { FY-94 BUDGET } & \$ 500.0 \mathrm{~K} \\ \text { FY-95 BUDGET } & \$ 650.0 \mathrm{~K} \\ \text { ACTIVITY TOTAL } & \$ 1150.0 \mathrm{~K}\end{array}$




\section{ACTIVITY: RESOLUTION OF BURIED WASTE ISSUE}

\section{B5. CRITICALITY}

\section{DESCRIPTION}

For some buried waste sites, there is the potential that the quantitics of lissile materials is sufficient for a criticality to occur during ISV processing. Mechanisms that can contribute to the concentration of fissile materials include: insolubility and pooling of the fissile materials in the ISV glass, densification of fissile materials prior to melt encapsulation, and entrainment and resulting condensation on the off-gas containment hood or in the off-gas treatment system.

The strong convective mixing characteristic of the ISV process, as well as the solubility of plutonium oxide in the molten soil, indicates that any concentration of fissile matcrials is unlikely. Research and development activities will focus on verifying these assumptions via engineering calculations, engineering-scale tests with plutonium simulants, and the identification of instrumentation to characterize the ISV melt (e.g., convective currents, chemical environment).

\section{BUDGET BASIS}

The budget basis is a project management estimate based on historical costs for similar type work. The work for resolution of this technical issue is broadly described above; however, specifics for this activity will not be known until the knowledge base is increased. Therefore, the budget presented below is an estimate and subject to change.

FY-94 BUDGET FY-95 BUDGET FY-96 BUDGET FY-98 BUDGET ACTIVITY TOTAL
$\$ 500.0 \mathrm{~K}$

$\$ 100.0 \mathrm{~K}$

$\$ 110.0 \mathrm{~K}$

$\$ 120.0 \mathrm{~K}$

$\$ 8.30 .0 \mathrm{~K}$ 


\section{ACTIVITY: INTERMEDIATE-SCALE SERIES I - STAGED SOIL SITE}

\section{DESCRIPTION}

This intermediate-scale field sest supports the resolution of the contaminated soil in situ vitrification (ISV) technical issues of (a) vapor release from unconfined soil and (b) fate of volatile organic compounds (VOCs). Data obtained from this field test will be used to verify applied research and development tools such as theoretical calculations and computer models. These research and development tools will be developed via the Technical Task Plans (TTPs) solicited by the ISV Integrated Program (ISV-IP). In addition, the data from this field test will be used to evaluate the merits of continued research efforts for the development of the ISV technology for application to buried waste.

\section{BUDGET AND PLANNING ASSUMPTIONS}

The project start date is $10 / 1 / 92$. ISV-IP TTP activities in early FY-93 will identify required ficld data. Tests will utilize nonregulated quantities of materials. The impact is (a) IntermediateScale tcst qualifies for categorical exclusion - minimal NEPA and (b) categorical exclusion precludes need for Environmental Assessment. A demonstration of contiguous melts requires a larger intermediate-scale hood. The test occurs at the Idaho National Engineering Laboratory (INEL) requiring $1 \mathrm{FTE}=1800$ hours (for one year).

\section{BUDGET BASIS}

The ISV staff at the Pacilic Northwest Laboratory (PNL) has conducted more than 40 previous ISV field tests and demonstrations. The experience gained from these ficld operations establishes the cost baseline for PNL ISV activities. A collaborative effort between PNL and the INEL on a 1990 field test at the INEL establishes the cost basis for INEL ISV activities. The cost estimates are reflective of the level of planning, documentation, training, operations, support services, equipment maintenance, analysis, and reporting that is typical of intermediate-scale field demonstrations. FY-92 baseline rates have been escalated at $5 \%$ per year to account for inflation.

\section{FY-93 BUDGET BREAKDOWN BY TASK}

Project Management and Administrative Control

Labor

INEL Project Management

Engineer

$1.68 \mathrm{FTE}$

0.50

Support

0.17

Nonlabor

(c.g., travel, graphics, duplicating)

TASK SUBTOTAL

$\$ 341.6 \mathrm{~K}$

Documentation

Labor

INEL Test Planning

INEL Safety Analysis

2.23 FTE

Engineer

2.40

0.30

$\$ 32.1 \mathrm{~K}$

$\$ 144.1 \mathrm{~K}$

$\$ 710.6 \mathrm{~K}$ 
Nonlabor

(c.g., graphics, duplicating, cditing)

TASK SUBTOTAL

System Preparation

Labor

INEL Site Preparation

$1.48 \mathrm{FTE}$

Engineer

0.20

Technician

0.13

Technical Specialist

0.24

PNL Crafts

0.13

Nonlabor

$\$ 723.6 \mathrm{~K}$

$\$ 329.6 \mathrm{~K}$

(e.g., electrodes, HEPA filters, thermocouples, maintenance parts)

INEL nonlabor

TASK SUBTOTAL

$\$ 100.0 \mathrm{~K}$

Equipment Modifications

$\$ 5.59 .6 \mathrm{~K}$

Labor

Engineer

0.42 FTE

$\$ 188.6 \mathrm{~K}$

Technician

Technical Specialist

0.43

PNL Crafts

0.21

Nonlabor

(c.g., Hood fabrication)

TASK SUBTOTAL

Operations Preparations

Labor

INEL ORR

Engincer

1.48 FTE

Technician

0.18

Technical Specialist

0.01

0.10

TASK SUBTOTAL

Operations

Labor

INEL Ficld Activities

2.86 FTE

Engineer

2.22

Technician

1.11

Technical Specialist

Nonlabor

0.68

$\$ 15(0.0 \mathrm{~K}$

$\$ 338.6 \mathrm{~K}$

$\$ 251.6 \mathrm{~K}$

(c.g.. travel, miscellaneous supplies)

$\$ 1(0) .0 \mathrm{~K}$

TASK SUBTOTAL

FY.93 TOTAL

$\$ 1148.9 \mathrm{~K}$

$\$ 3396.1 \mathrm{~K}$

\section{FY-94 BUDGET BREAKDOWN BY TASK}

Project Management and Administrative Control

Labor

$\$ 240.9 \mathrm{~K}$

B-16 
INEL Project Management

Engineer

Support

Nonlabor

(e.g., travel, graphics, duplicating)

TASK SUBTOTAL

Return to Standby

Labor

INEL Post Test Ficld Activities

Engineer

Technician

Technical Specialist

PNL Crafts

Nonlabor

(e.g., travel, supplies, parts)

TASK SUBTOTAL.

Sample Collection, Analysis, and Final Reporting

Labor

INEL Evaluation \& Analysis

Engineer 0.41

Technician

Technical Specialist

Nonlabor

(e.g., travel, graphics, duplicating, photography)

INEL nonlabor (lab analyses)

TASK SUBTOTAL
1.12 FTE

0.33

0.13

$\$ 25.0 \mathrm{~K}$

$\$ 265.9 \mathrm{~K}$

$\$ 416.1 \mathrm{~K}$

2.57 FTE

0.07

0.10

0.07

0.08

$\$ 9.0 \mathrm{~K}$

$\$ 425.1 \mathrm{~K}$

$\$ 288.9 \mathrm{~K}$

3.41 FTE

0.09

0.18

$\$ 68.0 \mathrm{~K}$

$\$ 191.0 \mathrm{~K}$

$\$ 547.9 \mathrm{~K}$

FY-93 TOTAL

$\$ 3396.1 \mathrm{~K}$

FY-94 TOTAL

$\$ 1576.2 \mathrm{~K}$

ACTIVITY TOTAL

$\$ 4972.3 \mathrm{~K}$ 


\section{ACTIVITY: INTERMEDIATE-SCALE SERIES II TEST 1 SINGLE PARAMETER BURIED WASTE SITE}

\section{DESCRIPTION}

This intermediate-scale field test is the lirst of two tests planned to support the resolution of technical issues associated with the application of ISV to buried waste. This field test is envisioned to utilize individually instrumented containers so as to provide insight into the fundamental mechanisms for the issues of (a) sealed containers/containment and (b) contaminant migration/underground fires. Data obtained from this field test will be used to verify applied research and development tools such as theoretical calculations and computer models. These research and development tools will be developed via Technical Task Plans (TTPs) solicited by the ISV Integrated Program (ISV.IP) or other organization.

\section{BUDGET AND PLANNING ASSUMPTICNS}

The project start date is 10/1/93. The Intermediate-Scale Series I results support continued buried waste evaluation. ISV-IP TTP, or other R\&D, activities in FY-93 identify required field data. The retrieval technology is to be determined as well as associated costs. The test will utilize nonregulated quantities of materials. The impact is (a) Intermediate-Scale test qualifies for catcgorical exclusion-minimal NEPA and (b) categorical exclusion precludes need for Environmental Assessment.

A new off-gas containment hood will be built for Intermediate-Scale Series I tests. Minimal equipment modifications are needed. The lest occurs at the Idaho National Engineering Laboratory (INEL) requiring 1 FTE $=1800$ ) hours (for one year).

\section{BUDGET BASIS}

The ISV stalf at the Pacific Northwest Laboratory (PNL) has conducted more than 40 previous ISV lickd lests and demonstrations. The experience gained from these field operations establishes the cost baseline for PNL ISV activities. A collaborative effort between PNL and the INEL on a 1990 field test at the INEL establishes the cost basis for INEL ISV activities. The cost estimates are reflective of the level of planning, training, documentation, operations, support services, equipment maintenance, analysis, and reporting that is typical of intermediate-scale tield demonstrations. FY-92 haseline rates have been escalated at $5 \%$ per year to account for inflation.

\section{FY'94 BUDGET BREAKDOWN BY TASK}

Project Management and Administrative Control

\section{Labor}

INEL Project Management

Engineer

Support

Nonlabor

(e.g., travel, graphics, duplicitingi;
$\$ 258.3 \mathrm{~K}$

1.06 FTE

0.44

0.17

TASK SUBTOTAL 
Test Documentation

Labor

INEL Test Planning

1.78 FTE

INEL Salety Analysis

2.16

Engineer

0.42

Technician Specialist

0.13

Support

0.04

Nonlabor

$\$ 669.9 \mathrm{~K}$

(e.g., graphics, duplicating, editing)

TASK SUBTOTAL

$\$ 12.0 \mathrm{~K}$

$\$ 681.9 \mathrm{~K}$

System Preparation

Labor

INEL Site Preparation

$\$ 278.8 \mathrm{~K}$

Engineer

1.18 FTE

Technician

0.14

0.11

Technical Specialist

0.22

PNL Crafts

0.12

Nonlabor

$\$ 62.0 \mathrm{~K}$

(e.g., electrodes, HEPA filters, thermocouples, maintenance parts)

INEL nonlabor

TASK SUBTOTAL

$\$ 80.0 \mathrm{~K}$

$\$ 420.8 \mathrm{~K}$

Operations Preparations

Labor

INEL ORR

Engineer

1.3.3 FTE

Technician

0.20

Technical Specialist

0.02

0.12

TASK SUBTOTAL.

$\$ 251.9 \mathrm{~K}$

Equipment Set-up

Labor

Engineer

Technician

0.40 FTE

0.20

Technical Specialist

0.10

Nonlabor

(e.g., travel, supplies)

TASK SUBTOTAL

FY-94 TO'TAL.

$\$ 122.7 \mathrm{~K}$

$\$ 251.9 \mathrm{~K}$ 
TASK SUBTOTAL

Operations

$\$ 215.5 \mathrm{~K}$

Labor

INEL Field Activitics

Engineer

Technician

Technical Specialist

Nonlabor

(c.g., travel, miscellaneous supplies)

TASK SUBTOTAL

Return to Standby

Labor

INEL Post Test Activities

Engineer

Technician

Technical Specialist

PNL Crafts

Nonlabor

1.43 FTE

1.82

0.94

0.48

$\$ 811.1 \mathrm{~K}$

(e.g., travel, supplies, parts)

TASK SUBTOTAL

Sample Collection, Analysis, and Final Reporting Labor

INEL Data Analysis Reporting

Engincer

Technician

Technical Specialist

Nonlabor

0.13 FTE

0.09

0.11

0.09

0.08

$\$ 84.0 \mathrm{~K}$

$\$ 895.1 \mathrm{~K}$

$\$ 84.5 \mathrm{~K}$

(c.g.. travel, graphics, duplicating, photography)

TASK SUBTOTAL

FY-94 TOTAL

FY.95 TOTAL

$\$ 1799.6 \mathrm{~K}$

$\$ 1592.4 \mathrm{~K}$

ACTIVITY TOTAL

$\$ 3.392 .0 \mathrm{~K}$ 
ACTIVITY: INTERMEDIATE-SCALE SERIES II TEST 2

SIMULATED BURIED WASTE SITE

\section{DESCRIPTION}

This intermediate-scale field test is the second of two tests planned to support the resolution of technical issues associated with the application of ISV to buried wastc. This field test is envisioned to simulate a typical INEL buried waste site. Technical issues which the field test supports are (a) sealed containers/containment, (b) contiguous melts/residual waste, and (c) contaminant migration/underground fires. Data obtained from this field test will be used to verify applied research and development tools such as theoretical calculations and computer models. These research and development tools will be developed via Technical Task Plans (TTPs) solicited by the ISV Integrated Program (ISV-IP) or other organization.

\section{BUDGET AND PLANNING ASSUMPTIONS}

The project start date is 10/1/94. The Intermediate-Scale Series II Test 1 results determine the Test 2 operating procedures. The ISV-IP TTP, or other R\&D, activities in FY-93 and FY-94 identify required field data. Retrieval technology is to be determined, as well as associated costs. The test will utilize nonregulated quantities of materials. The impact is (a) Intermediate-Scale test qualifies for categorical exclusion-minimal NEPA and (b) catcgorical exclusion precludes need for Environmental Assessment.

A new off-gas containment hood will be built for Intermediate-Scale Series I. Minimal equipment modifications are needed. The test occurs at the Idaho National Enginecring Laboratory (INEL) requiring $1 \mathrm{FIE}=1800$ hours (for one year).

\section{BUDGET BASIS}

The ISV staff at the Pacific Northwest Laboratory (PNL) has conducted more than 40 previous ISV field tests and demonstrations. The experience gained from these ficld operations establishes the cost baseline for PNL ISV activities. A collaborative effort between PNL and the INEL on a 1990) field test at the INEL establishes the cost basis for INEL ISV activities. The cost estinates are rellective of the level of planning, training, documentation, operations, support services, equipment maintenance, analysis, and reporting that is typical of intermediate-scale ficld demonstrations. FY-92 bascline rates have been escalated at $5 \%$ per year to account for inllation.

\section{FY-95 BUDGET BREAKDOWN BY TASK}

Project Management and Administrative Control

Labor

INEL Project Management

Engineer

Support

Nonlabor

(e.g., travel, graphics, duplicating)

TASK SUBTOTAL
$\$ 141.1 \mathrm{~K}$

0.19 FTE

0.44

0.17

$\$ 37.0 \mathrm{~K}$

$\$ 178.1 \mathrm{~K}$ 
Test Documentation

Labor

INEL Test Planning

$\$ 214.1 \mathrm{~K}$

INEL Safety Analysis

0.45 FTE

Engineer

0.2 .4

Technician Specialist

0.42

Support

0.13

0.04

Nonlabor

$\$ 13.5 \mathrm{~K}$

(e.g., graphics, duplicating, editing)

TASK SUBTOTAL

System Preparation

Labor

INEL Site Preparation

Engineer

$0.30 \mathrm{FTE}$

Technician

0.14

Technical Specialist

0.11

PNL Crafts

0.22

0.12

Nonlabor

$\$ 70.0 \mathrm{~K}$

(e.g., electrodes, HEPA filters, thermocouples, maintenance parts)

INEL nonlabor

TASK SUBTOTAL

$\$ 20 \mathrm{~K}$

$\$ 245.0 \mathrm{~K}$

Operations Preparations

Labor

INEL ORR

Engineer

0.15 FTE

$\$ 87.3 \mathrm{~K}$

Technician

0.20

Technical Specialist

TASK SUBTOTAL

0.02

0.12

Equipment Set-up

Labor

Engineer

Technician

$0.40 \mathrm{FTE}$

Technical Specialist

0.20

0.10

Nonlabor

$\$ 33.5 \mathrm{~K}$

(e.g., travel, supplies)

TASK SUBTOTAL

FY-95 TOTAL

$\$ 162.4 \mathrm{~K}$

$\$ 900.5 \mathrm{~K}$

\section{FY-96 BUDGET BREAKDOWN BY TASK}

Project Management and Administrative Control

Labor

INEL Project Management

Engineer

1.16 FTE

Support

0.50

0.17

$\$ 87.3 \mathrm{~K}$

$\$ 128.9 \mathrm{~K}$

Nonlabor

(c.g.. travel, graphics, duplicating)

$\$ 311.0 \mathrm{~K}$

$\$ 38.0 \mathrm{~K}$ 
TASK SUBTOTAL

$\$ 349 .(1) \mathrm{K}$

Operations

Labor

INEL Field Activities

1.43 FTE

Engineer

1.82

Technician

0.94

Technical Specialist

0.48

Nonlabor

$\$ 850.3 \mathrm{~K}$

(e.g., travel, miscellaneous supplies)

TASK SUBTOTAL

Return to Standby

Labor

INEL Post Test Activities

Engineer

2.44 FTE

Technician

0.09

Technical Specialist

0.11

0.09

PNL Crafts

0.08

Nonlabor

(c.g., travel, supplics, parts)

TASK SIJBTOTAL

Sample Collection, Analysis, and Final Reporting

Labor

INEL Analysis \& Reporting

Engineer

2.42 FTE

Technician

0.47

0.09

Technical Specialist

0.21

Nonlabor

(e.g., travel, graphics, duplicating, pholography)

INEL nonlabor

$\$ 89.6 \mathrm{~K}$

$\$ 939.9 \mathrm{~K}$

$\$ 448.9 \mathrm{~K}$

TASK SUBTOTAL

$\$ 846.1 \mathrm{~K}$

FY-95 TOTAL

$\$ 900.5 \mathrm{~K}$

FY-95 TOTAL

$\$ 2292.1 \mathrm{~K}$

ACTIVITY TOTAL

$\$ 3192.6 \mathrm{~K}$ 


\section{ACTIVITY: LARGE-SCALE ISV DEMONSTRATION SIMULATED BURIED WASTE SITE}

\section{DESCRIPTION}

This large-seale field demonstration on a full-scale simulation of a buried waste site will be used to collect the data to resolve technical issues associated with ISV processing of buried waste. The data from a full-scale unit is needed due to the scalability issue between waste simulants at the intermediate-scale and the actual buried waste scale. For example, it is unclear whether the gas release mechanism from a 55-gallon drum is the same as that for a 2.5 -gallon drum (scaled representation of a 55-gallon drum used in intermediate-scale tests). In addition, to fully support the Remedial Investigation/Feasibility Study (RI/FS) Report, the ISV technology must provide data representative of full-scale application.

\section{BUDGET AND PLANNING ASSUMPTIONS}

The project start date is $1 / 1 / 96$. The Intermediate-Scale Series II results support proceeding with a large-scale demonstration. A large-scale operation is performed with Geosafe equipment and personnel. Retrieval technology is to be determined, as well as associated costs. Intermediate-Scale Series II results will dictate required equipment modifications; no major equipment modifications are identified for this budget estimate. The test occurs at the Idaho National Engineering Laboratory (INEL) requiring 1 FTE $=1800$ hours (for one year).

\section{BUDGET BASIS}

The ISV stalf at the Pacific Northwest Laboratory (PNL) has conducted more than 40 previous ISV ficld tests and demonstrations. The experience gained from these field operations establishes the cost bascline for PNL ISV activitics (no historical data is currently available to support Geosale operating cost estimate). A collaborative effort between PNL and the INEL on a 199() field test at the INEL establishes the cost basis for the INEL ISV activities. The cost estimates are rellective of the level of planning, training, documentation, operations, support services, equipment maintenance, analysis, and reporting that is typical of intermediate-scale field demonstrations. FY-92 baseline rates have been escalated at $5 \%$ per year to account for inflation.

\section{FY-96 BUDGET BREAKDOWN BY TASK}

Project Management and Administrative Control Labor

INEL Project Management

Engineer

Support

Nonlabor

(c.g.. travel, graphics, duplicating)

TASK SUBTOTAL

Test Documentation

Labor

INEL Test Planning
$\$ 309.3 \mathrm{~K}$

1.03 FTE

0.50

0.30

$\$ 46.5 \mathrm{~K}$

$\$ 355.8 \mathrm{~K}$

$\$ 872.8 \mathrm{~K}$

2.23 FTE 
INEL Safety Analysis

Technician Specialist

0.22

Support

0.07

Nonlabor

$\$ 1(x) .0 \mathrm{~K}$

(Geosale subcontract)

TASK SUBTOTAL

$\$ 972.8 \mathrm{~K}$

Data Collection Preparation, Setup, Training

Labor

INEL Site Preparation

1.48 FTE

Engineer

0.31

Technician

0.22

Technical Specialist

0.22

PNL Crafts

0.27

Nonlabor

$\$ 100.0 \mathrm{~K}$

(e.g., monitoring eq., thermocouples, flowmeters)

INEL nonlabor

$\$ 100.0 \mathrm{~K}$

TASK SUBTOTAL

$\$ 644.0 \mathrm{~K}$

FY-96 TOTAL

$\$ 1972.6 \mathrm{~K}$

FY-97 BUDGET BREAKDOWN BY TASK

Project Management and Administrative Control

Labor

INEL Project Management

1.04 FTE

Engineer

(0.5)

Support

0.30

Nonlabor

$\$ 33.0 \mathrm{~K}$

(c.g., travel, graphics, duplicating)

TASK SUBTOTAL

Finalize Test Documentation

Labor

INEL ORR

Engineer

$\$ 324.3 \mathrm{~K}$

Technical Specialist

$\$ 357.3 \mathrm{~K}$

$\$ 277.2 \mathrm{~K}$

1.48 FTE

0.11

0.07

Nonlabor

$\$ 25.0 \mathrm{~K}$

(Geosafe subcontract)

TASK SUBTOTAL

Operations (Setup, Operations, Return to Standby)

Labor (Data Collection)

INEL Ficld Activitics

2.86 FTE

INEL Post Test Activities

2.57

Engineer

0.09

Technician

0.27

Technical Specialist

0.09

$\$ 3(12.2 \mathrm{~K}$

$\$ 967.8 \mathrm{~K}$

Nonlabor

$\$ 935.0 \mathrm{~K}$

(e.g., travel and Geosafe subcontract) 
TASK SUBTOTAL

Sample Collection, Analysis, and Quick Look Report

Labor

Engineer

Technician

Technical Specialist
0.21 FTE

0.11

0.16

Nonlabor

(c.g., graphics, duplicating, photography, Geosafe subcontract) TASK SUBTOTAL

FY-97 TOTAL

$\$ 181.5 \mathrm{~K}$

$\$ 2743.5 \mathrm{~K}$

\section{FY-98 BUDGET BREAKDOWN BY TASK}

Project Management and Administrative Control

Labor

INEL Project Management

0.73 FTE

Engineer

0.33

Support

0.22

Nonlabor

$\$ 2.36 .3 \mathrm{~K}$

(e.g., travel, graphics, duplicating)

TASK SUBTOTAL

$\$ 30.0 \mathrm{~K}$

$\$ 266.3 \mathrm{~K}$

ISV Block Sampling and Analysis

Labor

INEL Product Analysis

Engineer

1.05 FTE

Technical Specialist

0.13

0.09

Nonlabor

$\$ 282.9 \mathrm{~K}$

(Analytical services)

INEL nonlabor, lab analyses

TASK SUBTOTAL

Data Reduction and Final Reporting

Labor

INEL Reporting

Engineer

Technical Specialist

$\$ 50.0 \mathrm{~K}$

$\$ 191.0 \mathrm{~K}$

$\$ 52.3 .9 \mathrm{~K}$

Nonlabor

$\$ 110.0 \mathrm{~K}$

(c.g.. graphics, duplicating, photography, Geosafe subcontract)

TASK SUBTOTAL

$\$ 678.3 \mathrm{~K}$

FY-96 TOTAL

FY-97 TOTAL

$\$ 1972.6 \mathrm{~K}$

FY-98 TOTAL

$\$ 2743.5 \mathrm{~K}$

$\$ 678.3 \mathrm{~K}$

ACTIVITY TOTAL

$\$ 5394.4 \mathrm{~K}$ 


\section{ACTIVITY: LARGE-SCALE HANFORD 200-BP-1 ISV DEMONSTRATION RESOLUTION OF DEPTH ISSUE}

\section{DESCRIPTION}

Westinghouse Hanford Company Environmental Restoration Program (WHC-ERP) is including the ISV technology in its Five-Year Plan beginning in FY.94. One of the demonstrations included in this plan is a. ISV melt depth demonstration to assist in the closure of the depth issue. This demonstration supports the ER Demonstration in 1998 for 200-BP-1 and will demonstratc the ISV technology for applications greater than 5 meters.

\section{BUDGET BASIS}

The budget for this activity is to be included in the WHC-ERP Five-Year Plan. Detailed breakdown of this activity by task is to performed in the year prior to start-up of activities (i.e., detailed breakdown for FY-94 would occur in FY-93).

$\begin{array}{ll}\text { FY-95 BUDGET } & \$ 1310.0 \mathrm{~K} \\ \text { FY-96 BUDGET } & \$ 1350.0 \mathrm{~K} \\ \text { FY-97 BUDGET } & \$ 664.0 \mathrm{~K} \\ \text { FY-98 BUDGET } & \$ 407.0 \mathrm{~K} \\ \text { ACTIVITY TOTAL } & \$ 3731.0 \mathrm{~K}\end{array}$


Appendix C

\author{
In Situ Vitrification \\ Technology Transfer Plan
}


C-2 


\section{Appendix C}

\section{In Situ Vitrification \\ Technology Transfer Plan}

\section{INTRODUCTION}

May 7, 1992

This Technology Transfer Plan is being prepared as a mechanism to enhance the use of in situ vitrification (ISV) technology, where appropriate, at Department of Energy (DOE) sites. This plan is being patterned after Pacific Northwest Laboratory's Five-Year Strategic Plan for Technology Transfer (1991) and the Idaho National Engineering Laboratory's Standard Practice Manual Technology Transfer Operations (1992). Both documents provide guidance on how to properly conduct a technology transfer program, and applicable elements have been incorporated into this plan.

\section{GOALS}

The goal of the ISV technology transfer plan is to (a) provide the strategy for transferring ISV technology to DOE customers, (b) provide the implementation activities necessary to conduct a successful technology transfer program, (c) identify the roles and responsibilities of the principal players involved with transferring the technology, and (d) identify funding responsibilities for technology transfer and related activities. The desired end result is to facilitate the technology transfer process for ISV and apply it at those sites where significant needs exist.

\section{STRATEGY}

The strategy of the In Situ Vitrification Integrated Program's technology transfer plan is to create, manage, and motivate an environment where technology transfier is an integral part of the Integrated Program and each of the Technical Task Plans funded by the Integrated Program. The technology transfer plan will be implemented by three major strategic elements:

- Technical outreach (prior to identification of a specific site need for the technology)

- Information exchange (at the time of identification of a specific site need)

- Technical assistance and collaboration, including involvement and participation by customer (throughout the resolution of issues and implementation processes for a specilic site).

\section{IMPLEMENTATION}

Implementation of the technology transfer program will be performed primarily at the worker level (i.e., with the contractor and DOE field office staff directly responsible for cleanup of a waste site or group of waste sites). The objective of each strategic element and the activities necessary to implement the technology transfer strategy by the contractor staff are described in this section. 


\section{Technical Outreach}

The objective of the technical outreach element is to enhance recognition of ISV's capabilities in resolving specific and general problems facing DOE's Office of Environmental Restoration and Waste Managoment. This means matching specific DOE site needs with current and future capabilities of the ISV technology in a way that is faster, better, cheaper, and/or safer. In other words, the objective of outreach is to identify those needs where ISV can (a) achicve site cleanup faster than currently established baselines or other alternatives being considered, ( $h$ ) achieve greater volume and/or toxicity reduction through a greater level of destruction or more le waste form, (c) achieve significantly lower cradle-to-grave costs when compared with retricval, treatment, arid disposal alternatives or other in situ treatment alternatives, and/or (d) achieve reduced risks of exposure to workers, the environment, and the public. Measurement of this objective is obtained by inclusion of ISV in the customer organization's plans to implement ISV either as a permanent or interim measure, include ISV in the Record of Decision (ROD) evaluation (or equivalent) process, and inclusion of ISV in the customer's demonstration plans for new technology in support of its ROD cvaluation (or equivalent) process.

Certain tools will be provided for performing the outreach activities. One is the documentation of the current capabilities and limitations of the ISV process. This documentation, provided in Attachment A, will be an aid to Integrated Program staff, its principal investigators, and its customers in matching needs with capabilitics.

Outreach is performed jointly under the leadership of PNL and its technology development counterparts at the customer's site. Communication vehicles include site visits and meetings with the customer organization (Environmental Restoration contractor and DOE Ficld Office staff), participation in workshops and national conferences, publication and distribution of research results, and distribution of Integrated Program activities such as weekly reports and update bulletins.

\section{Information Exchange}

Once the Outreach portion of this program is successful in including ISV in a specific waste site's implementation, evaluation, or demonstration plans, Integrated Program stalf, PNL's technology development staff, and the customer's technology development staff will begin an information exchange process with customer staff. This process is intended to identify the specific activities that need to be performed to successfully implement ISV into the customer's waste site plans. Integrated Program and technology development staff from PNL will meet collectively with technology development staff from the customer's organization and the customer to identify and agree upon open technical and regulatory issues facing the implementation process. Those issues being resolved by the Integrated Program will be identified. Specilic Technical Task Plans charged with resolving these issues will be identified and copies will be provided to the customer. Those issues that meel a DOE complex-wide need and are not currently being resolved by the Integrated Program will be identified. Integrated Program stafl will determine with its DOE field office and HQ staff, whether the issue(s) will be aceepted by the Integrated Program for resolution. Considerations of priority and available resources will factor into this decision. If aceepted, technology need statements will be issued to solicit solutions to the issues from DOE laboratories, universitics, and private industry. Those issues not aceepted by the Integrated Program for resolution will be identified for resolution 
by the customer. With assistance from PNL's Integrated Program stafit and the customer's technology development staff, a plan for resolution of these site specific issues will be prepared.

chnical Assistance and Collaboration

The third element of the ISV lechnology transfer strategy provides for the continued technical assistance by ISV technology development staff throughout the resolution of issues and implementation stages. It also provides for continued participation by customer staff in the ISV Integrated Program during resolution of issues.

Technology Development stalf, both at PNL and the customer's organization, will take the lead in resolving issues according to Technical Task Plans supported by the ISV Integrated Program. They will be assisted, as needed by other DOE laboratories, universities, private industry, and the customer. In order to achieve greater participation by the customer (c.g., EM-40) during resolution of issucs, they will be invited to participate in Techrical Task Plans funded by the Integrated Program. Principal investigators are encouraged to utilize customer expertise and capability in resolving technical issues, especially in terms of lield test planning and operations.

One method of easing the transition of the technology to the customer is to involve these same partics in resolving site spevific and remaining issues necessary for implementation at the customer's site. Such a strategy will preserve ecentinuity and expertise for the most eflicient implementation of ISV at the :ustomer's site.

In addition, technical assistance will be provided at the customer's discretion, by the lechnology development staft who have led the activities in the resolution of issucs. This technical assistance will be provided in the areas of demonstration planning or remedial design, operations, and evaluations of the demonstration $o_{1}$ remediation activity. It is the continued intention of the ISV Integrated Yrogram to financially support and participate in these demonstrations/remediations as well as to collect field data during and alter operations to help confirm resolution of issues. The final evaluation of the performance of the ISV technology for the customer's demonstration or remediation lies with the customer.

\section{ROLES AND RESPONSIBILITIES}

This section is a description of the roles and responsibilities of cach party associated with successfully carrying out this Technology Transier Plan. Table C-1 provides a summary description of each organization's responsibilities as identified in the description of wach strategy element.

ISV Integrated Program Staff. The Integrated Program staff refers to the Contractor Technical Cocrdinator (CTC) and/or his assignes delegates. The (TC is James L. Buclt of Pacific Northwest Laboratory. He is responsible for carrying out the objects: so the Inte'srated Program which include implementing the technology for near-term applications and coordinating tasks to resolve technical and regulatory issues impeding implementation. Should the Integrated Program be combined with another Integrated Program in the future, such as the In Situ Remediation Integrated Program, this citcgory will refer to the leader of the Technical Support Group for In Situ Vitrification. 


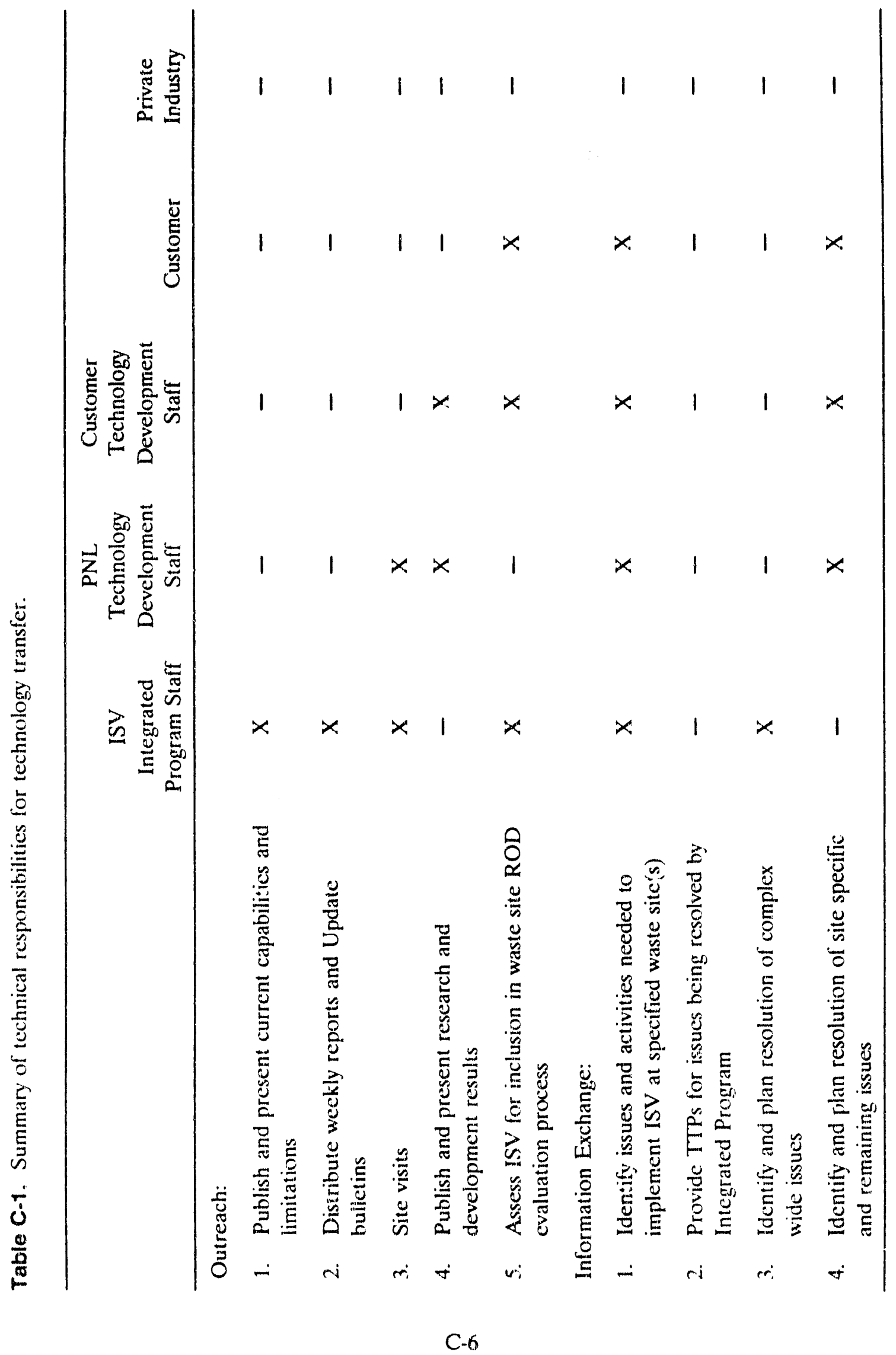




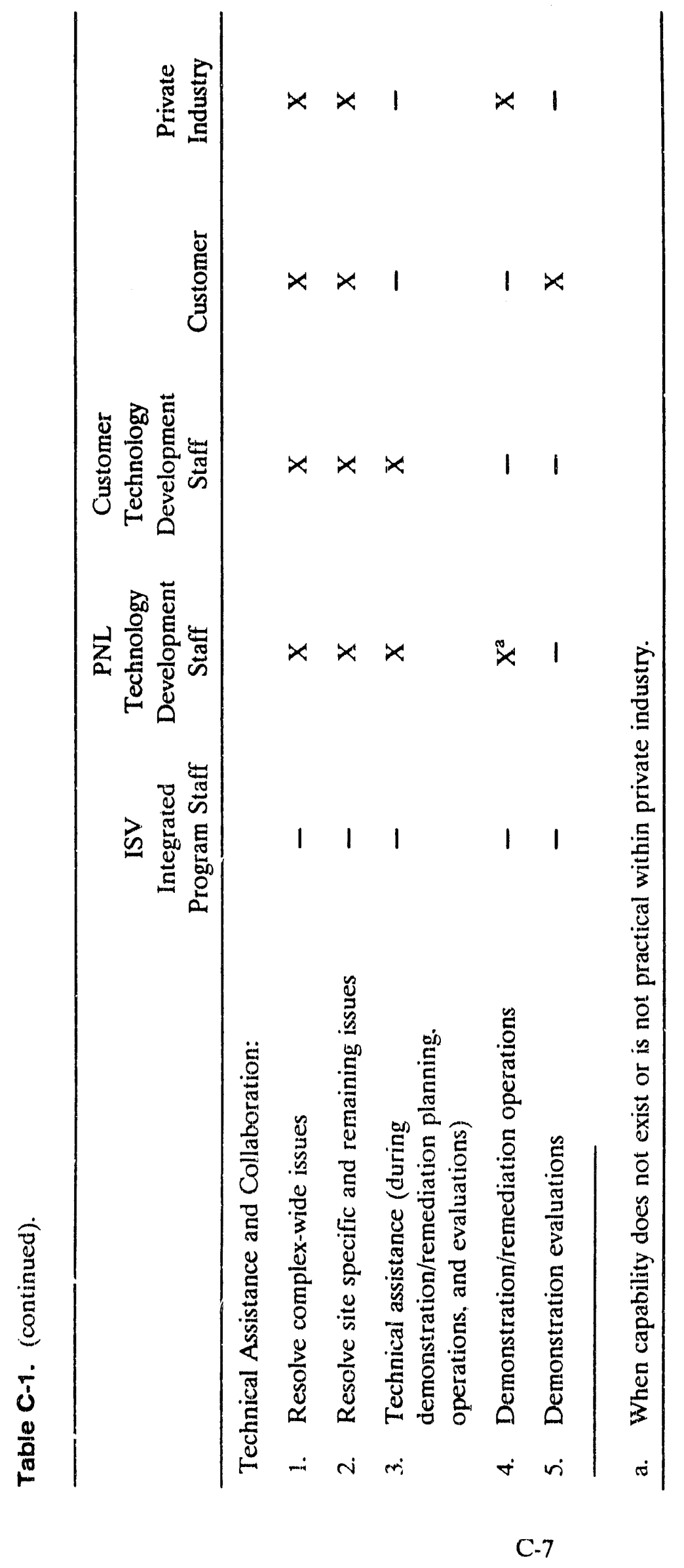


PNL ISV Technology Develonment Staff. PNL ISV Technical Staff refers to the staff members within several PNL organizations who participate in the development of ISV and have extensive experience (12 years) in design, fabrication, operation, planning, and evaluation of ISV technology. This group is represented by the ISV Group Leader within the Waste Technology Center, Leo Thompson, but involves staff from several organizations within PNL.

Customer's Technology Development Staff. The Customer's Technology Development Staff refers to staff members within the customer's laboratory who participate in the development of ISV, either through funding from the ISV Integrated Program or other Integrated Demonstrations or Programs supporting development and demonstration of ISV.

Customer. The customer refers to any entity or organization within DOE or its contractors who have a need for ISV technology to resolve their waste problems. This generally refers to the DOE contractor's Environmental Restoration divisions funded by EM-40, the Office of Environmental Restoration. However, in many cases it may refer to an Integrated Demonstration within DOE's Office of Technology Development. In this case, the Customer's Technology Development staff and customer staff are the same.

Private Industry. Private industry refers to those organizations that provide ISV remediation and support services, such as Geosafe Corporation of Kirkland, Washington. It also refers to those industrial firms and universities who participate in the resolution of issues facing the ISV Integrated Program.

\section{FUNDING AND STAFFING}

Table $\mathrm{C}-2$ provides a summary of the source of funding for conducting activities associated with this Technology Transfer Plan. The funding responsibilities associated with the ISV Integrated Program are attributed to the ISV Planning and Coordination Technical Task Plan whereas those associated with PNL and Customer Technology Development Projects are attributed to the various ISV Integrated Program Technical Task Plans associated with resolution of issues. For those activities that have multiple funding resources identified in the table, each funding resource would be responsible for funding its staff for their respective contributions to that activity.

Costs for conducting the outreach portion of this technology transfer plan are borne in part by the ISV Integrated Program and by Federal government programs at PNL and the customer's technology development organization that directly benefit by transfer of ISV technology to the customer. Internal organization funding is also an important resource to the PNL and Customer Technology Development Projects for conducting site visits and assessing ISV for inclusion in waste site ROD evaluation processes.

Costs for conducting the information exchange element of this strategy will be borne by the same resources, but may also need to be supplemented by the customer, depending on the complexity of issues needing resolution. This level of support, if needed, will be negotiated with the customer.

Costs for techrical assistance and customer participation during resolution of issues provided in the third element of this strategy will be attributed to either the Integrated Program's technical tasks or the customer, depending on which organization has agreed to fund resolution of the appropriate technical issue. Technical assistance and customer participation during the implementation, ROD evaluation, or demonstration phases will be costed to the customer. 


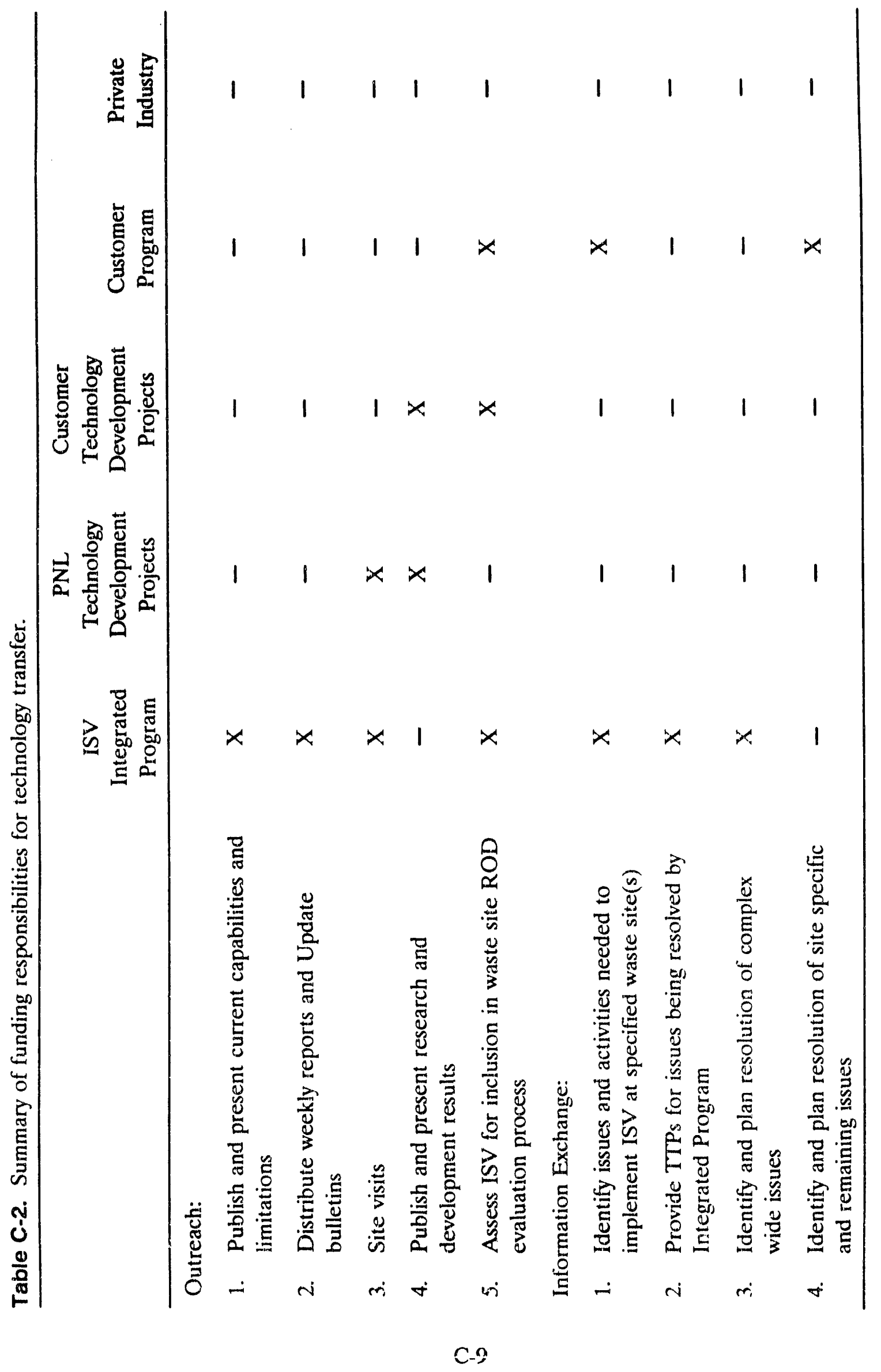




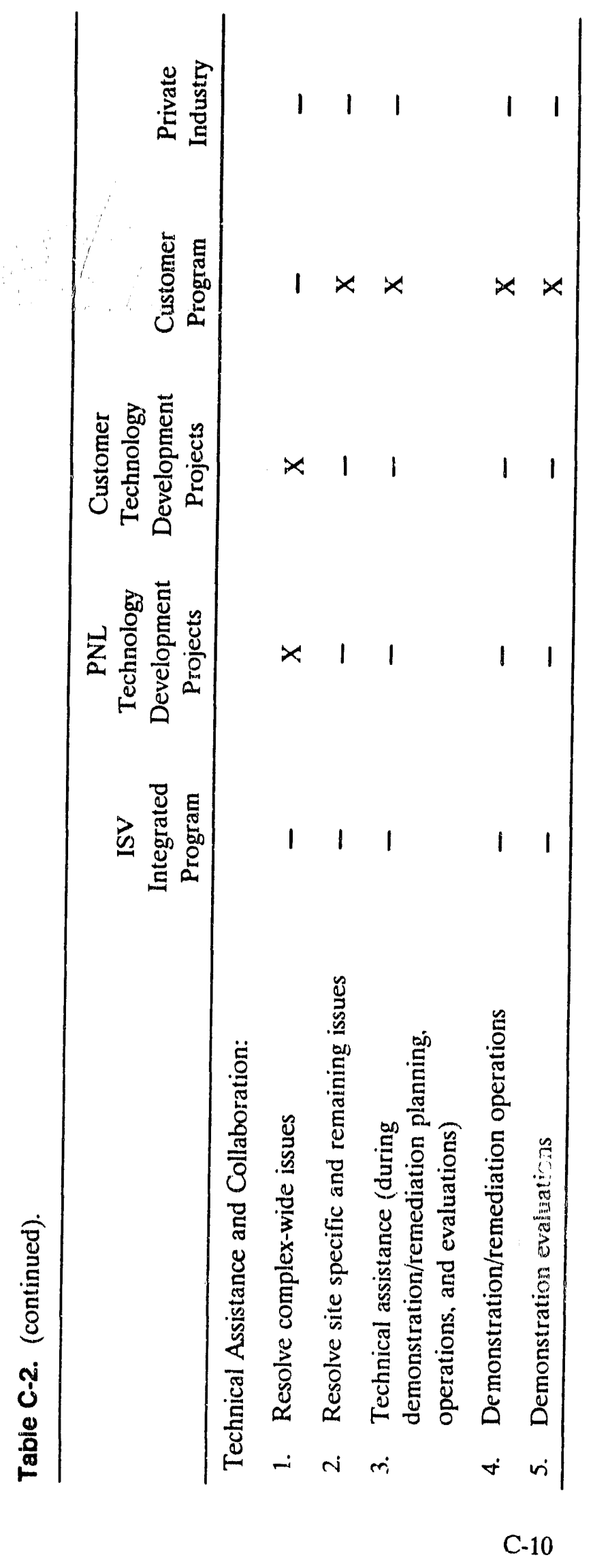




\section{Attachment A}

Current Capabilities and Limits of In Situ Vitrification 


\section{Attachment A \\ Current Capabilities and Limits of In Situ Vitrification}

April 14, 1992

As a result of over 150 ISV tests and a variety of theoretical analyses, operational capabilities for the ISV technology have been established. The capabilities (limits) listed below represent the position of Pacific Northwest Laboratory relative to the current state of the technology based on the present understanding of the process and capabilities of existing process equipment. As technological advances are realized, these operational capabilities will be revised accordingly.

Soil Type ISV applications should be limited to sand or clay soil types that have a high vapor permeability when dry. These soils have permeabilities greater than approximately $10^{-3} \mathrm{~cm} / \mathrm{s}$ and allow the relatively unrestrained release of gas and vapor through the dry soil column surrounding a melt. Special monitoring and/or analyses must be taken when vitrifying silty soils or non-swelling clays. These materials generally have lower permeabilities (i.e., less than $10^{-3} \mathrm{~cm} / \mathrm{s}$ ) even after being dricd out. Sandy soils and clays that shrink and crack when dried out are relatively permeable. They allow release of water vapor evaporated from the soil being vitrified to the surface easily, precluding the potential for water vapor pressure buildup bencath the block in excess of the static head pressure of the glass. The ISV Integrated Program is planning to refine operational capabilities through analysis and experimentation for the lower permeability soils and sludge. Geosafe is planning to have a near-term modeling parametric study performed relating effects of permeability, soil type, melt rate, melt size, and boundary condition inclusions.

Soil Moisture ISV is generally applicable for soils regardless of moisture content. Soils and sludge ranging from $4 \mathrm{wt} \%$ moisture to $70 \mathrm{wt} \%$ have been successfully vitrified. The amount of water associated with silty soils or non-swelling clays becomes important in the analysis relative to the ability of the soil column to dissipate the vapor generated at the melt front. The water content and the permeability of the soil must be evaluated in combination to determine the effective processing rate (vapor generation rate) so that the generation rate does not exeed the ability of the soil column to dissipate the vapor.

The process is not applicable for soils that lie within a permeable aquifer (i.e., greater than $10^{-4} \mathrm{~cm} / \mathrm{s}$ permeability), unless combined with a groundwater diversion or pumping technique during processing to limit recharge rate.

Soil Composition A minimal alkali content of $1.5 \mathrm{wt} \%$ is required for ISV applications. Because most soils and sludge are naturally composed of glass forming materials such as silica, they are generally processable by ISV without modification. However, the minimum alkali content (i.c., combined $\mathrm{Na}_{2} \mathrm{O}$ and $\mathrm{K}_{2} \mathrm{O}$ content) of 1.5 wt $\%$ is necessary. Alkaline oxides are responsible for carrying the electrical current 
Depth of Contamination

Radionuclides

Hazardous Inorganic Chemicals among electrodes in the molten state. Weathered soils with less than $1.5 \mathrm{wt} \%$ oxides require addition and mixing of alkaline materials to lower melting temperature and raise electrical conductivity. The ISV Integrated Program is planning to develop techniques to process weathered soils without soil modification.

The ISV process should not be applied beyond depths of $19 \mathrm{ft}$ and any depth goal must be evaluated relative to the stratigraphy and physical characteristics of the site. The ISV process has been demonstrated at depths up to $19 \mathrm{ft}$ in relatively homogenous soils. However, the achievable depth can be limited under certain heterogenous conditions where heat transfer is less efficient, such as the presence of a rock or gravel layer, or a layer of soil that inas a significantly higher melting temperature than the overlying material. Depths of $14 \mathrm{ft}$ and $17 \mathrm{ft}$ have been achieved when similar heterogeneous conditions existed at those depths. In addition, the relative density of the soils to be processed influences the achievable melt depth. Higher density soils require more time and energy to be processed. The ISV Integrated Program has marle significant progress in developing a technique lor increasing the depth capability to beyond $30 \mathrm{lt}$, and the program anticipates this technique to be available in 1994 .

There are no foreseeable ISV applications that would approach the limits for radionuclide concentrations relative to processing or product quality. Because the ISV process was originally developed for transucanic contaminated soils, the process proved extremely effective in immobilizing radionuclides, including transuranic materials and fission products. Criticality limits have been established via conservative analyses at approximately $30 \mathrm{~kg}$ of ${ }^{\mathrm{u}} \mathrm{u}$ per setting. Generally, this means that soil concentrations at thousands of $\mathrm{nCi} / \mathrm{g}$ of TRU can be treated safely via ISV. When unusually high concentrations of Cs exist (i.c., multiple curies per setting), special measures must be taken to collect the small percentage (i.e., less than $3 \mathrm{wt} \%$ ) of Cs that is volatilized and return it to the melt to avoid high worker exposure. The ISV Integrated Program is currently engaged in developing and evaluating these techniques.

There are no foreseeable ISV applications that would approach limits of hazardous inorganic metals. ISV is extremely effective in immobilizing heavy metals and other inorganic contaminants. The majority (between 70 and $99.99 \mathrm{wt} \%$ ) of heavy metals such as $\mathrm{As}, \mathrm{Pb}, \mathrm{G}, \mathrm{Ba}$, and $\mathrm{Cr}$ are retained and immobilized in the vitrified product. The remainder are collected by the off as system and either returned to the melt or disposed of separately. Mercury is removed and collected by the offgas system for recovery or disposal. Higher concentrations of nitrates $(>10 \mathrm{wt} \%)$ may pose problems relative to product durability; however, this issue could be evaluated via treatability testing. Assuming nitrates are distributed in the soil column and do not exist in concentrated pockets, off-gassing of NOx is not anticipated to be a problem. Nitrates distributed in the soil column are decomposed by the process to form $\mathrm{N}_{2}$ and $\mathrm{O}_{2}$. 
Hazardous

Organic

Chemicals

Scrap Metals

Jebris and

Buricd

Cornbustibles
Rubble

Based on current equipment design capabilities relative to heat loading, a limit of 7 wt\% organics has been established. When processing sites with high concentrations of organics, an evaluation of the total gas and water vapor that will be generated must be evaluated relative to the ability of the soil column to dissipate these gases. Because of its high processing temperature, ISV destroys hazardous organic chemicals by pyrolysis. Organic concentrations up to $7 \mathrm{wl} \%$ in the soil are processable by ISV. The small pereentage of organic contaminants not destroyed by the process (between 0.01 and $1 \mathrm{wt} \%$ ) are removed from the soil by the process and collected by the offgas treatment system. ISV should not, however, presently be applied to reactive or explosive materials. Although limited empirical data shows that volatile organic contaminants (VOCs) are effectively treated, their fate during processing is not yet certain and requires completion of theoretical and empirical studies by the ISV Integrated Program. Because VOCs, such as carbon tetrachloride and trichloroethylene, have boiling points near or less than that of water, simpler ways could be used to remove and treat them, and they would not normally be a target contaminant for ISV processing. However, when VOCs coexist with other target contaminants, such as PCBs, radionuclides, or heavy metals, their fate during processing becomes an important consideration. Until definitive results are available from the Integrated Program, treatability testing on contaminant specific soils is an effective method of determining applicability of ISV to specific soil types and their contaminants. Treatability studies can be used to resolve this issue on a site-specilic basis. Meanwhile, the ISV Integrated Program is currently engaged in activities that determine the fate of VOCs under a variety of processing conditions.

With the recently developed electrode feed system, which permits the electrodes to be inserted into the soil as the soil is melted downward, high scrap metal concentrations are processable by ISV (e.g., 25 wt\% of metals have been demonstrated).

Inclusions of high concentrations of concrete rubble, rock, and other debris (up to $5.5 \mathrm{w}(\%)$ are generally processable by ISV, as long as all other operational constraints are met. Monolithic debris and structures configured in a fashion that would provide a barrier to water vapor release from beneath the molten soil to the soil surface should be avoided without sufficient analyses of the effects of the debris.

Based on current heat removal capabilitics of the process, combustible inclusions up to 7 wt? are processable by ISV. Evaluations should be conducted to determine the effect of buried combustibles on off-gas generation rate both relative to off-gas containment and the ability of the soil column to dissipate the gases. Although limited field data for buried combustible materials exists, during a 1990 large-scale demonstration, more than 80 creosote timbers (12 ft long by 6 in. square) were successfully processed without incident.

Scaled Containers The ISV process should not be applied to sites where there is the potential for sealed containers such as drums or even small 1-gal paint cans. Additionally, since 
unsealed or corroded containers have the ability to contain pooled liquids, ISV should not be used on sites where the presence of buried containers is known or suspected. The concern of sealed containers involves the potential over expulsion of molten glass when these containers are breached during melting. Similar concerns exist for pocketed liquids. Once the ISV process is being successfully implemented in the field on contaminated soils, the ISV Integrated Program will develop techniques for such advanced applications, if warranted.

Multiple small voids in the soil of up to $2.5 \mathrm{ft}^{3}$ each can be processed by ISV. Larger single void volumes should be collapsed or filled to preclude the possibility of generating a large bubble (i.e., $>3 \mathrm{ft}$ bubble) in the melt. Large bubbles can splatter unacceptable quantities of molten glass inside the hood when released at the molten surface. 

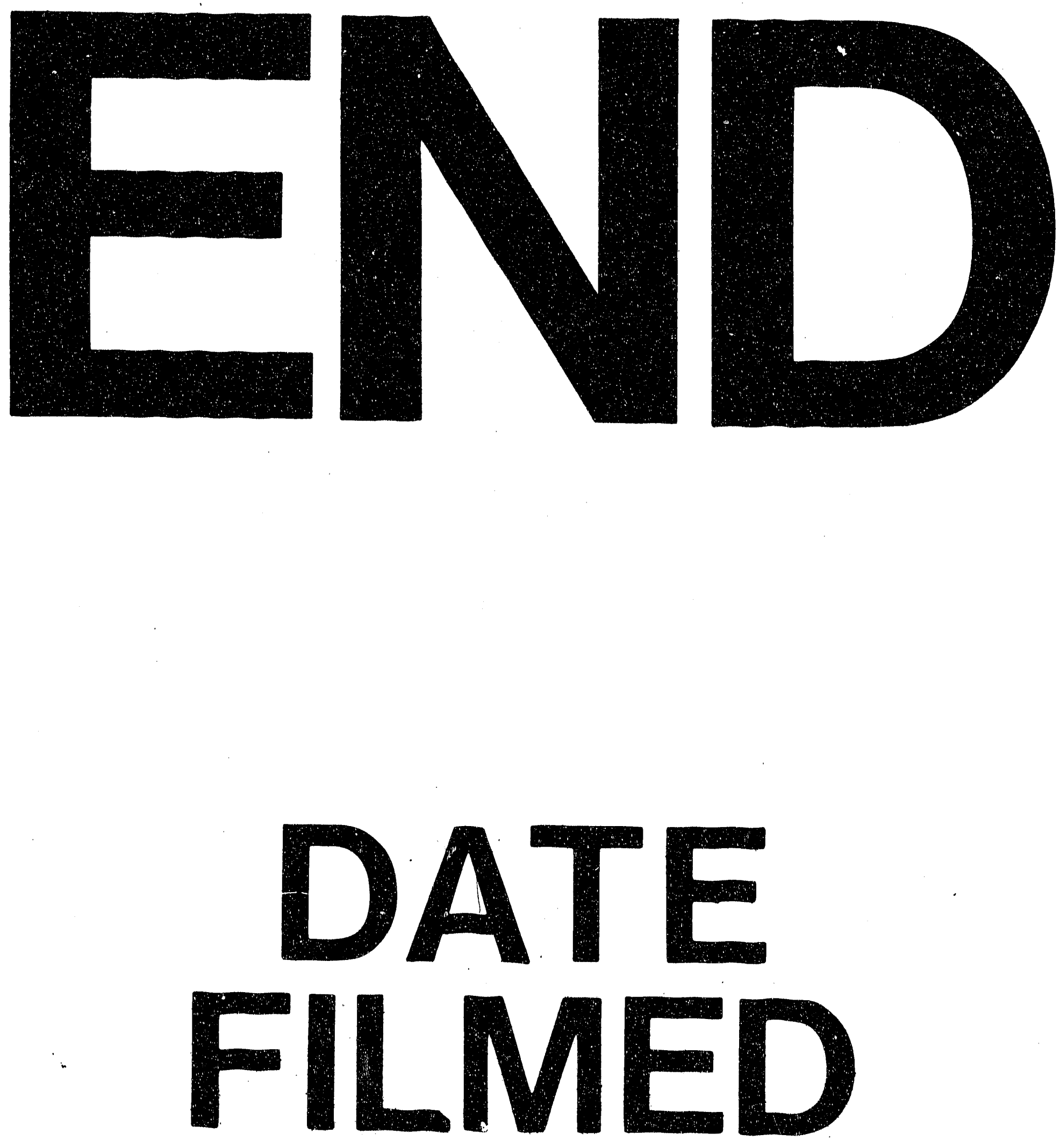

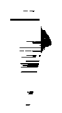

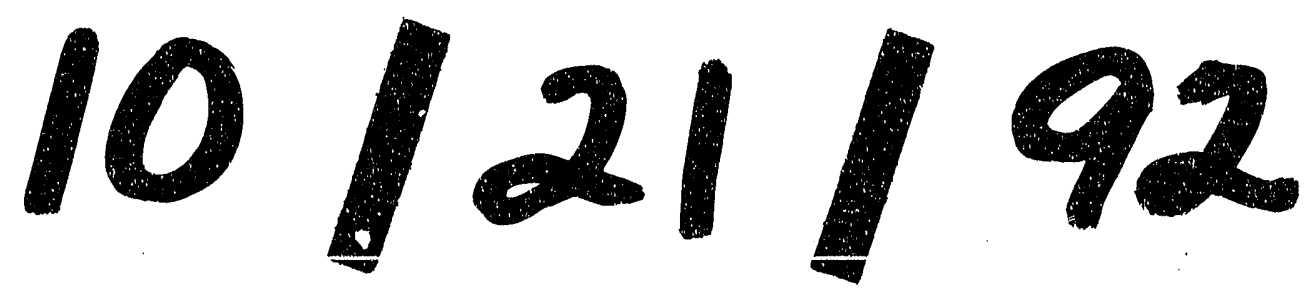


